\title{
Changes in the in vitro activity of platinum drugs when administered in two aliquots
}

\author{
Zaynab Al-Eisawi ${ }^{1,6}$, Philip Beale ${ }^{2}$, Charles Chan ${ }^{3}$, Jun Qing Yu', Nicholas Proschogo ${ }^{4}$, Mark Molloy ${ }^{5}$ \\ and Fazlul Huq, ${ }^{1,7^{*}}$
}

\begin{abstract}
Background: The management of ovarian cancer remains a challenge. Because of the lack of early symptoms, it is often diagnosed at a late stage when it is likely to have metastasized beyond ovaries. Currently, platinum based chemotherapy is the primary treatment for the disease. However acquired drug resistance remains an on-going problem. As cisplatin brings about apoptosis by intrinsic and extrinsic pathways, this study aimed to determine changes in activity of platinum drugs when administered in two aliquots as against a bolus and sought to determine association with changes in GSH, speciation of platinum drugs and changes in protein expression.

Methods: The efficacy of administering cisplatin, carboplatin and oxaliplatin in two aliquots with a time gap was investigated in ovarian A2780, A2780 cisR,$A 2780^{2 D 0473 R}$ and SKOV-3 cell lines. The cellular accumulation of platinum, level of platinum - DNA binding and cellular glutathione level were determined, and proteomic studies were carried out to identify key proteins associated with platinum resistance in ovarian A2780 ${ }^{\text {cisR }}$ cancer cell line.
\end{abstract}

Results: Much greater cell kill was observed with solutions left standing at room temperature than with freshly prepared solutions, indicating that the increase in activity on ageing was related to speciation of the drug in solution. Proteomic studies identified 72 proteins that were differentially expressed in A2780 and A2780 ${ }^{\text {cisR }}$ cell lines; 22 of them were restored back to normal levels as a result of synergistic treatments, indicating their relevance in enhanced drug action.

Conclusions: The proteins identified are relevant to several different cellular functions including invasion and metastasis, cell cycle regulation and proliferation, metabolic and biosynthesis processes, stress-related proteins and molecular chaperones, mRNA processing, cellular organization/cytoskeleton, cellular communication and signal transduction. This highlights the multifactorial nature of platinum resistance in which many different proteins with diverse functions play key roles. This means multiple strategies can be harnessed to overcome platinum resistance in ovarian cancer. The results of the studies can be significant both from fundamental and clinical view points.

Keywords: Cisplatin (CS), Carboplatin (CB), Oxaliplatin (OX), Drug combination, Synergism, Drug uptake, Drug resistance, Aging effect

Abbreviations: ACN, Acetonitrile; ACTB, Actin, cytoplasmic 1; ANXA1, Annexin A1; ATPA, ATP synthase subunit alpha, mitochondrial; CALR, Calreticulin; CALU, Calumenin; CB, Carboplatin; CBDCA, Cyclobutanedicarboxylate; CH60, 60 kDa heat shock protein, mitochondrial; $\mathrm{Cl}$, Combination index; CID, Collision induced dissociation; COF2, Cofilin-2; COX5A, Cytochrome c oxidase subunit 5A, mitochondrial; CS, Cisplatin; CTR1, Copper transporter 1; Cu, Copper; (Continued on next page)

\footnotetext{
* Correspondence: Fazlul.Huq@sydney.edu.au

${ }^{1}$ Discipline of Biomedical Science, Sydney Medical School, University of Sydney, Sydney, NSW 2141, Australia

${ }^{7}$ Discipline of Biomedical Science, School of Medical Sciences, Sydney

Medical School, The University of Sydney, Cumberland Campus C42, 75 East

Street, Lidcombe, NSW 1825, Australia

Full list of author information is available at the end of the article
} 


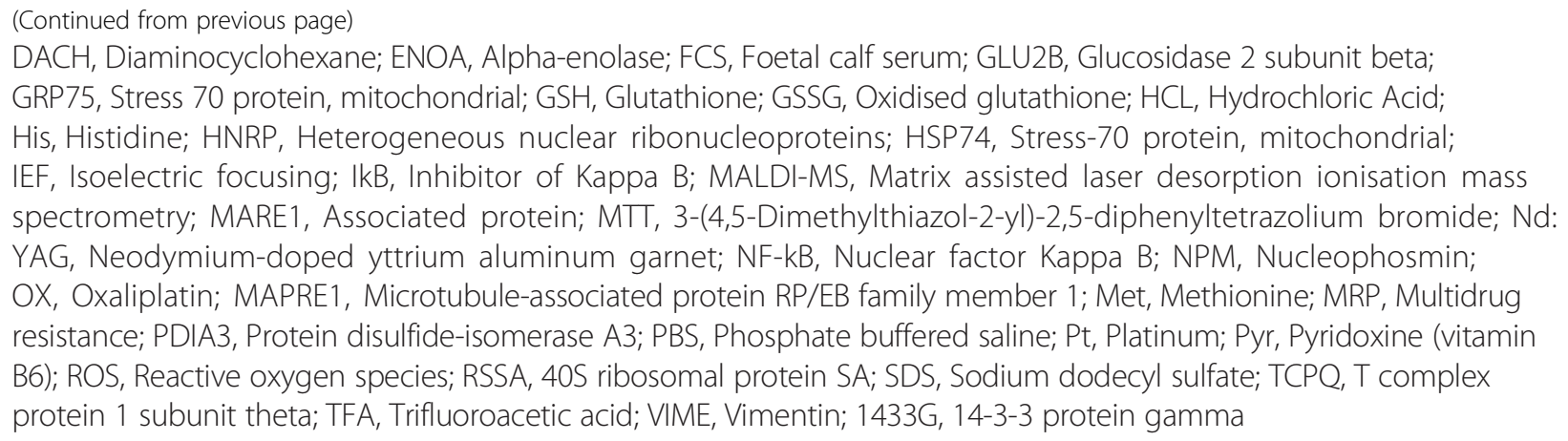

\section{Background}

Platinum-based drugs cisplatin (CS), carboplatin (CB), and oxaliplatin (OX) are routinely used in the clinic to treat various cancers including testicular, ovarian, lung, bladder, colon, head and neck cancers [1]. However, efficacy is limited by dose limiting toxicities and acquired drug resistance [2] that may arise due to decreased cellular accumulation of platinum drugs, inactivation by conjugation with glutathione or sequestration involving metallothionein, enhanced tolerance to platinum-DNA adducts and enhanced DNA repair mechanisms [2, 3].

Cancer related pathways are bound to be highly complex often involving both intrinsic and extrinsic pathways [4]. As applied to cell death caused by CS, it was suggested that depending on the status of the cell, different pathways would become more significant at different time points. We proposed that the administration of first aliquot of CS would place cancer cells under increased oxidative stress caused by depletion of cellular thiols due to their binding with the drug [5] and if so when the second aliquot was administered after a brief time period ( 2 to $4 \mathrm{~h}$ ), depleted glutathione level would allow more of the drug to bind with DNA resulting into increased apoptosis. Thus, the sequenced administration of CS in two aliquots with a small time gap could be looked upon as being the combination of two drugs with somewhat different mechanisms of action [5].

The present study aimed to determine the efficacy of the administration of CS, CB and OX (Fig. 1) in two aliquots with time gaps of $2,4,8,24 \mathrm{~h}$ in ovarian tumour models. We also sought to determine whether the use of 'aged solutions' of the drugs (where the solutions for the second aliquots were left standing at room temperature for the duration of the time gap) had a similar or greater effect on cell kill. The rationale behind using both fresh and aged solutions was to determine the effect of hydrolysis of platinum drugs on the combined drug action. Although platinum - DNA binding is believed to be an essential step in CS induced apoptosis, the programmed cell death is brought about downstream by multiple proteins. Thus, the study also aimed to determine changes in expression of key proteins associated with drug resistance in ovarian cancer cell lines.

\section{Methods \\ Materials}

CB and OX were obtained from Sigma Aldrich, Sydney, Australia. CS was synthesized according to previously described method [6]. Foetal calf serum (FCS), RPMI1640, $200 \mathrm{mM} \mathrm{L-glutamine,} \mathrm{and} 5.6 \%$ sodium bicarbonate were obtained from Trace Biosciences Pty Ltd Australia. DNA extraction kit JETQUICK Blood DNA Spin Kit/50 was obtained from Astral Scientific Pty Ltd, Sydney, Australia. GSH/GSSG-Glo ${ }^{\mathrm{Tm}}$ assay kit was obtained from Promega, Sydney, Australia. Other chemicals were obtained mostly from Sigma-Aldrich, Sydney, Australia. Ovarian cancer A2780, A2780 ${ }^{\text {cisR }}$, A2780 ZD0473R and SKOV-3 cell lines were gifts from Ms. Mei Zhang, Royal Prince Alfred Hospital, Sydney, Australia. Stock solutions of platinum drugs were prepared to a final concentration of $1 \mathrm{mM}$; CS was first dissolved in DMF then made up in milli- $Q$ water to a final ratio of 1:4 DMF to milli-Q water, whereas $\mathrm{CB}$ and $\mathrm{OX}$ were prepared in milli-Q water only. Stock solutions were then filtered to insure sterility.

\section{Cell culture}

Human ovarian cancer A2780, A2780 cisR, A2780 ZD0473R and SKOV-3 cell lines (Table 1) were seeded in $25 \mathrm{~cm}^{2}$ tissue culture flasks in an incubator at $37{ }^{\circ} \mathrm{C}$ in a humidified atmosphere consisting of $5 \% \mathrm{CO}_{2}$ and $95 \%$ air. The cells were maintained in logarithmic growth phase in complete medium consisting of RPMI 1640, $10 \%$ heat inactivated FCS, $20 \mathrm{mM}$ Hepes, $0.11 \%$ bicarbonate, and $2 \mathrm{mM}$ glutamine without antibiotics [7]. Each cell line was seeded at a density of $4-6 \times$ $10^{3}$ cells/well in flat-bottomed 96-well culture plate in $10 \%$ FCS/RPMI 1640 culture medium. The plate was 


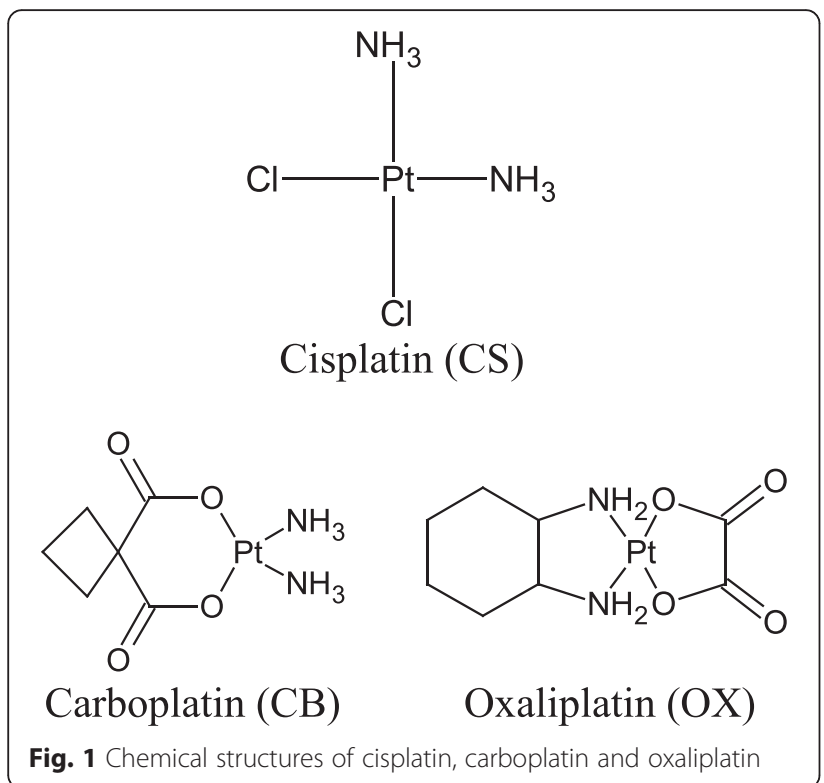

incubated for $24 \mathrm{~h}$ at $37{ }^{\circ} \mathrm{C}$ in a humidified atmosphere allowing cells to attach.

\section{Cytotoxicity assay}

MTT reduction assay was carried out to determine cytotoxicity of CS, CB and OX administered as a bolus and in two aliquots with a time gap. Stock solutions of drugs were subjected to serial dilutions to give final concentrations ranging from 0.16 to $250 \mu \mathrm{M}$. The dilutions were performed using $10 \%$ RMPI-1640 medium without serum as the vehicle and were added to equal volumes of cell culture in triplicate wells and then cells were left to incubate for $72 \mathrm{~h}$. These treatments were carried out to determine $\mathrm{IC}_{50}$ values i.e. drug concentrations required for $50 \%$ cell kill. In treatment in two aliquots with a time a gap, cells were treated with solutions of $\mathrm{CS}, \mathrm{CB}$ and $\mathrm{OX}$ at three different concentrations based on their $\mathrm{IC}_{50}$ values. The first aliquot administered at time zero was that of a freshly prepared solution (denoted as 'fresh') whereas the second aliquot administered at $2 \mathrm{~h}(0 / 2 \mathrm{~h}), 4 \mathrm{~h}(0 / 4 \mathrm{~h}), 8 \mathrm{~h}(0 / 8 \mathrm{~h})$ or $24 \mathrm{~h}(0 / 24 \mathrm{~h})$ was using either freshly prepared solution (fresh) so that the combination was termed fresh/fresh or aged solution left at room temperature for the period of the time gap

Table 1 Human ovarian cancer cell lines used in this study

\begin{tabular}{|c|c|}
\hline Cell line & Phenotype \\
\hline $\mathrm{A} 2780$ & Untreated ovarian tumour \\
\hline $\mathrm{A} 2780^{\mathrm{cisR}}$ & CS resistant ovarian tumour \\
\hline $\mathrm{A} 2780^{\mathrm{ZD} 0473 R}$ & ZD0473 ${ }^{\mathrm{a}}$ resistant ovarian tumour \\
\hline SKOV-3 & Oestrogen receptor positive ovarian tumour \\
\hline
\end{tabular}

aZD0473 (also known as JM473 and AMD 473) is a sterically hindered platinum complex with a cis-geometry like cisplatin (denoted as 'aged') so that the combination was termed fresh/aged. Cells in drug free medium served as control. The rationale behind doing experiments with both fresh and aged solutions was to determine the effect of hydrolysis of platinum drugs on the combined drug action. The period of drug treatment was $72 \mathrm{~h}$ counted from the time of administration of the first dose. Cell growth inhibition was determined using the MTT reduction assay. Combination index values (CIs) were used as measures of synergism, additiveness or antagonism calculated using the program CalcuSyn [8-10] and previously described method [11].

\section{Platinum accumulation and platinum-DNA binding}

Cellular accumulation of platinum and platinum - DNA binding levels in A2780 and A2780 ${ }^{\text {cisR }}$ cell lines were determined as applied to administration of CS in two aliquots with a time gap of 2 and $4 \mathrm{~h}$ and at a final concentration of $50 \mathrm{mM}$, for both fresh/fresh and fresh/ aged combinations. The drug was added to culture plates containing exponentially growing A2780 and A2780 cisR cells in $10 \mathrm{ml} 10 \%$ FCS/RPMI 1640 culture medium (cell density $=5 \times 10^{6}$ cells $\left./ \mathrm{ml}\right)$. The cells containing the drug were incubated for $24 \mathrm{~h}$ at the end of which cell monolayers were collected and cell suspensions $(10 \mathrm{ml})$ were transferred to centrifuge tube and spun at $3500 \mathrm{rpm}$ for 2 min at $4{ }^{\circ} \mathrm{C}$. The cells were washed twice with ice-cold phosphate-buffered saline (PBS) and the pellets were stored at $-20{ }^{\circ} \mathrm{C}$ until assayed. At least three independent experiments were performed.

\section{Cellular accumulation}

Following drug incubation the cell pellets were suspended in $0.5 \mathrm{ml} 1 \%$ triton-X, held on ice then sonicated. Total intracellular platinum contents were determined by graphite furnace atomic absorption spectrophotometry.

\section{Drug-DNA binding}

High molecular weight DNA from cell pellets were isolated using JETQUICK Blood DNA Spin Kit/50 (Astral Scientific, Australia) according to the modified protocol of Bowtell [12]. Platinum contents of the samples were determined by graphite furnace AAS. $A_{260} / A_{280}$ ratios were found to be between 1.75 and 1.8 for all samples, indicating high purity of the DNA.

\section{Cellular glutathione}

As a measure of cellular health and the redox state of the cells, the levels of total glutathione (GSH and GSSG) and oxidised glutathione (GSSG) in A2780 and A2780 ${ }^{\text {cisR }}$ cell lines were determined as applied to treatments with $\mathrm{CS}$ and $\mathrm{CB}$ administered in two aliquots with a time gap of $4 \mathrm{~h}$. Drugs made in $10 \%$ RMPI-1640 serum free medium were added to equal volumes of cell 
culture wells of a white wall clear bottom 94 well plate containing exponentially growing A2780 and A2780 ${ }^{\text {cisR }}$ cells (cell density $=12 \times 10^{3}$ cells/well). Cells were left to incubate for $24 \mathrm{~h}$. The medium was aspirated out of the treatment wells with minimal disturbance of the cell pellets and cells were washed with $200 \mu \mathrm{l}$ of PBS, then the levels of glutathione were determined using the GSH/ GSSG-Glo $^{\mathrm{Tm}}$ Assay kit (Promega, Australia). The plate was read in a LUMIstar Omega luminometer (BMG LABTECH, USA).

\section{Mass spectral analysis}

Mass spectrometry was used to explore hydrolysis of OX rather than that of CS as OX and its hydrolysis products were more sensitive to mass spectral measurements than those of CS. Solution of OX first made in milli-Q water, was diluted (1:2) with methanol, cell culture medium, or $\mathrm{pH}$ adjusted (neutral) milli-Q water. The solutions were injected by syringe pump (flow rate $150 \mathrm{ul} / \mathrm{h}$ ) into a Bruker Apex Qe $7 \mathrm{~T}$ Fourier Transform Ion Cyclotron Resonance Mass Spectrometer (FTICR) in positive ion electrospray ionization mode. The instrument was optimized and externally mass calibrated before use. The presence and evolution of OX species was monitored over a period of $4 \mathrm{~h}$, with measurements made every hour.

\section{Proteomics}

Proteomic studies were carried to determine the proteins that were differentially expressed in the parent A2780 and cisplatin-resistant A2780 ${ }^{\text {cisR }}$ cell lines but were restored back due to treatment with CS in two aliquots. Ovarian cancer A2780 and A2780 ${ }^{\text {cisR }}$ cell lines were cultured in $50 \mathrm{~cm}^{2}$ petri dishes to produce at least a million cells per dish. Cells were treated with solutions of CS (at $\mathrm{IC}_{50}$ ) administered as a bolus and in two aliquots with $2 \mathrm{~h}$ time gap using both aged and fresh solutions $(\mathrm{CS}+\mathrm{CS}(2 / 0 \mathrm{~h})$ aged/aged and CS + CS $(2 / 0 \mathrm{~h})$ fresh/fresh). Untreated control cells were also included. The period of incubation with the drugs was $24 \mathrm{~h}$. Following drug treatment, cell pellets were collected, rinsed with ice-cold PBS and centrifuged at $3500 \mathrm{rpm}$ for $2 \mathrm{~min}$ at $4{ }^{\circ} \mathrm{C}$. The pellets were lysed in a cell lysis solution containing $2 \mathrm{M}$ thiourea, $8 \mathrm{M}$ urea, $4 \%$ CHAPS, $65 \mathrm{mM}$ dithiothreitol (BIORAD, Australia). Isoelectric focusing (IEF) of the sample containing $200 \mu \mathrm{g}$ of proteins was performed using $11 \mathrm{~cm}, \mathrm{pH}$ 3-10 non-linear ReadyStrip $^{\text {Tw }}$ IPG Strip in Protean i12 IEF cell unit (BIORAD, Australia) rehydrated in $8 \mathrm{M}$ urea, $2 \mathrm{M}$ thiourea, $4 \%$ CHAPS, $60 \mathrm{mM}$ dithiothreitol, $0.2 \%$ carrier ampholyte, $0.0002 \%$ bromophenol blue and deStreak (BIORAD, Australia). Two equilibration steps of the IPG were performed in SDS equilibration buffer containing SDS, $6 \mathrm{M}$ urea, 50 \% glycerol, $1.5 \mathrm{M}$ Tris $\mathrm{HCl}(\mathrm{pH} 8.8)$, and bromophenol blue with the first containing $0.5 \mathrm{~g}$ dithiothreitol and the second $0.5 \mathrm{~g}$ iodoacetamide. Protein concentration was determined using Bio-Rad Protein Assay (BIO-RAD, Australia). SDS-PAGE was performed using 4-20 \% SDS Criterion ${ }^{\mathrm{Tm}} \mathrm{TGX}^{\mathrm{Tw}}$ pre-cast gels in a Criterion Dodeca $^{\text {Ti }}$ cell separation unit (BIO-RAD, Australia) at constant $200 \mathrm{~V}$ for $100 \mathrm{~min}$ in a Trisglycine- $\mathrm{HCl}$ buffer system. The gels were stained with Bio-Safe Coomassie Stain (BIO-RAD, Australia) for $60 \mathrm{~min}$. At least a duplicate of gels containing protein spots from the same sample were used for analysis. The gel images obtained by ChemiDoc ${ }^{\mathrm{mm}}$ MP Imaging system (BIO-RAD, Australia) were analysed for protein spots using Melanie version 7.0 software (GeneBio, Switzeland). A 2.0 fold change in the expression of a protein across the matched groups was used as the cut-off for differential expression. Analysis of variance (ANOVA), a statistical tool used to detect differences between experimental group means, was performed using a target significance level of 0.05 .

\section{MALDI-TOF/TOF MS}

Protein spots were excised from preparative 2-D gels stained with Bio-Safe Coomassie Stain (BIO-RAD, Australia). The spots were destained with $120 \mu \mathrm{l}$ of $\left(50 \%\right.$ acetonitrile $(\mathrm{ACN}) / 50 \mathrm{mM} \mathrm{NH} \mathrm{NCO}_{3}$ ) solution and heated at $37{ }^{\circ} \mathrm{C}$ for $30 \mathrm{~min}$ with mild shaking. The solution was then discarded. The gels were treated with $25 \mu \mathrm{l} \mathrm{ACN}$ and left to dry for $15 \mathrm{~min}$. The solution was discarded then the spots were left to dry with the lid left open in the oven at $37^{\circ} \mathrm{C}$ for $15 \mathrm{~min}$ followed by cooling at $4{ }^{\circ} \mathrm{C}$. The spots were digested with $10 \mu \mathrm{l}$ trypsin for $10 \mathrm{~min}$ on ice. The trypsin supernatants were placed in 96-well plate at $4{ }^{\circ} \mathrm{C}$ followed by $10 \mu \mathrm{l}$ addition of $25 \mathrm{mM} \mathrm{NH}_{4} \mathrm{HCO}_{3}$ for overnight digestion at $37{ }^{\circ} \mathrm{C}$. The resulting peptides were extracted with $0.1 \%$ trifluoroacetic acid (TFA) then extracted and concentrated by $\mathrm{C} 18$ zip-tips (Millipore, $\mu$-C18, P10 size) on Xcise (Proteome Systems). A $1 \mu \mathrm{l}$ aliquot was manually spotted onto a MALDI AnchorChip plate with $1 \mu \mathrm{l}$ of matrix (CHCA, $1 \mathrm{mg} / \mathrm{mL}$ in $90 \% \mathrm{v} / \mathrm{v} \mathrm{ACN}, 0.1 \%$ TFA) and left to dry in air. Matrix assisted laser desorption ionisation mass spectrometry (MALDI-MS) was performed with 4800 plus MALDI TOF/TOF Analyser (AB Sciex). A neodymium-doped yttrium aluminum garnet (Nd:YAG) laser $(355 \mathrm{~nm})$ was used to irradiate the sample. Spectra were acquired in reflectron MS scan mode in the mass range of 700-4000 Da. The instrument was then switched to MS/MS (TOF-TOF) mode where the eight strongest peptides from the MS scan were isolated and fragmented by collision induced dissociation (CID), then re-accelerated to measure their masses and intensities. A near point calibration was applied and would give a typical mass accuracy of $50 \mathrm{ppm}$ or less. The data on 
peptides masses were analysed using database search program Mascot (Matrix Science Ltd, London, UK). The peak lists were searched against Homo sapiens entries in the SwissProt database. The protein identification was undertaken at Australian Proteome Analysis Facility (APAF) the infrastructure provided by the Australian Government through the National Collaborative Research Infrastructure Strategy (NCRIS).

\section{Results}

\section{Cytotoxicity}

Figure 2 shows the cell survival fractions versus concentration plots for $\mathrm{CS}, \mathrm{CB}$, and $\mathrm{OX}$ as applied to the human ovarian cancer A2780, A2780 ${ }^{\text {cisR }}$, A2780 ${ }^{\text {ZD0473R }}$ and SKOV-3 cell lines. The $\mathrm{IC}_{50}$ values of $\mathrm{CS}, \mathrm{CB}$ and $\mathrm{OX}$ are presented in Table 2. As expected, the values were higher in the resistant $\mathrm{A} 2780^{\text {cisR }}, \mathrm{A} 2780^{\mathrm{ZD} 0473 \mathrm{R}}$ and SKOV-3 cell lines with OX having the largest value in SKOV-3. The parent A2780 cell line was most sensitive to the drugs, $\mathrm{A} 2780^{\mathrm{ZD} 0473 \mathrm{R}}$ was least sensitive to $\mathrm{CB}$ and SKOV-3 was least sensitive to OX.

\section{Administration in two aliquots}

Figure 1 gave the combination index $(\mathrm{CI})$ values applying to administration of CS, CB and OX in two aliquots with a time gap of $2,4,8$, or $24 \mathrm{~h}$ to the ovarian cancer A2780, A2780 ${ }^{\text {cisR }}, A 2780^{\text {ZD0473R }}$ and SKOV-3 cell lines where $\mathrm{CI}$ values of $<1,=1$ and $>1$ indicated respectively synergism, additivity and antagonism in combined action. Cells were treated with solutions of CS, CB and $\mathrm{OX}$ at three different concentrations based on their $\mathrm{IC}_{50}$ values. When CS was administered in two aliquots (fresh/aged), the killing of A2780 cells was most pronounced when the time gap was $8 \mathrm{~h}$; all other time gaps were found to be additive to antagonistic. In A2780 $0^{\text {cisR }}$ cell line, much pronounced cell kill was observed for time gaps of 2, 4 and $8 \mathrm{~h}$ and antagonism was observed when it was increased to $24 \mathrm{~h}$. In A2780 ${ }^{\text {ZD0473R }}$ cell line also, extremely pronounced cell kill was observed for time gaps of 2, 4 and $8 \mathrm{~h}$ and reduced cell kill was observed when this was increased to $24 \mathrm{~h}$. In SKOV-3 cell line, synergistic cell kill was observed only for the $24 \mathrm{~h}$ time gap. When $\mathrm{CB}$ was administered in two aliquots (fresh/aged) in A2780 cell line synergistic kill was observed when the time gap was 4,8 or 24 h. It was most pronounced when the time gap was 4 and $8 \mathrm{~h}$ but antagonistic when the time gap was $2 \mathrm{~h}$. In $\mathrm{A} 2780^{\text {cisR }}$ cell line, pronounced cell kill was observed for the time gaps of 2 , 4 and $8 \mathrm{~h}$ and reduced cell kill was observed when it was $24 \mathrm{~h}$. In A2780 ${ }^{\mathrm{ZD} 0473 \mathrm{R}}$ cell line also, extremely pronounced cell kill was observed for time gaps of 2, 4 and $8 \mathrm{~h}$ and reduced cell kill was observed when this was increased to $24 \mathrm{~h}$. In SKOV-3 cell line, antagonism was observed for all time gaps.

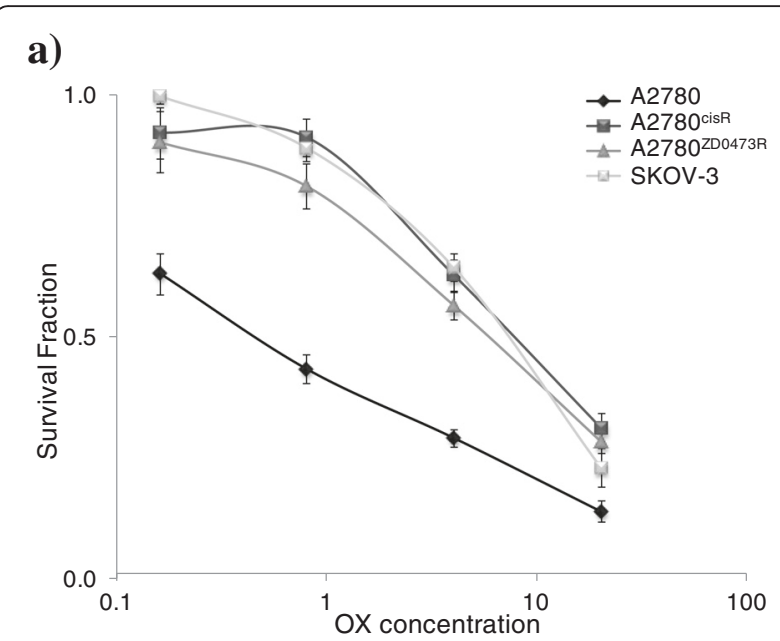

b)

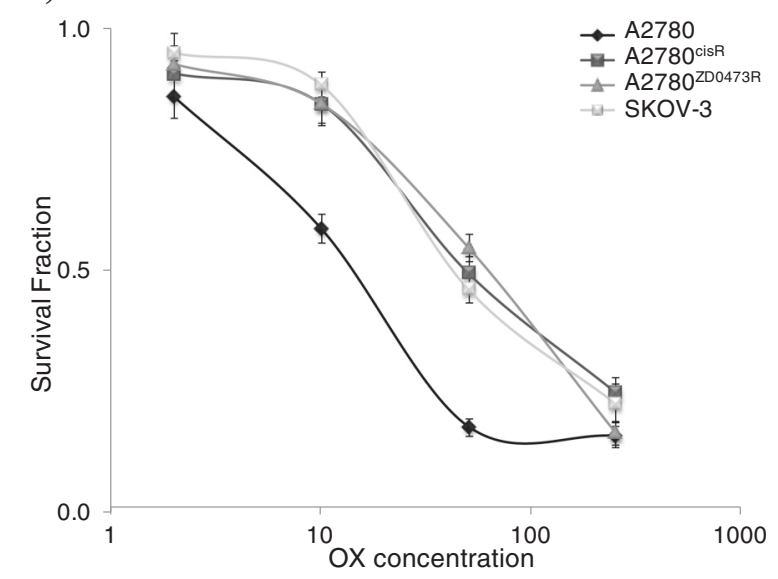

c)

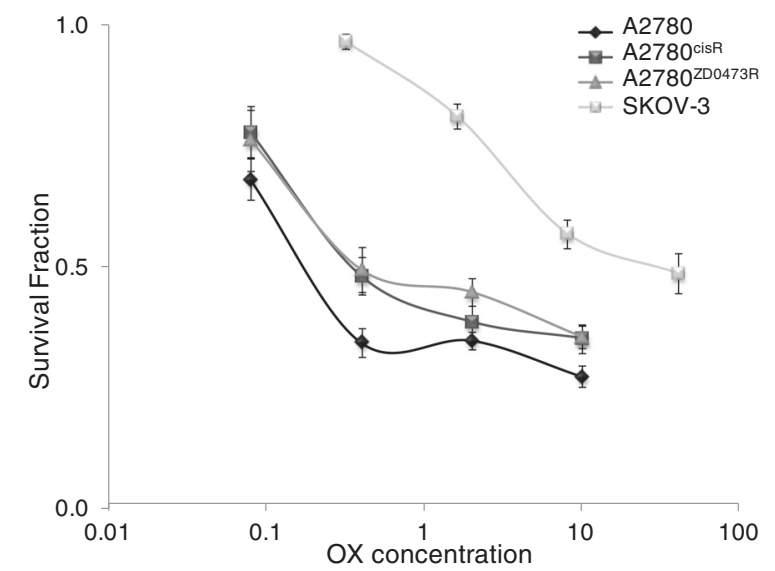

Fig. 2 Cell growth inhibition following increasing concentrations of platinum drugs. Cell survival fractions of ovarian cancer A2780, A2780 cisR, $\mathrm{A} 2780^{\mathrm{ZD} 0473 \mathrm{R}}$ and SKOV-3 cell lines following treatment with increasing concentrations of $\mathbf{a} \mathrm{CS}, \mathbf{b} \mathrm{CB}$ and $\mathbf{c}$ OX for $72 \mathrm{~h}$ were determined using MTT assay and spectrophotometric measurement. Error bars represent the standard deviation (where straight lines or curves containing the dot points are meaningless) 
Table 2 Summary of the $\mathrm{IC}_{50}$ values $(\mu \mathrm{M})$ and resistance factors (RF) for CS, CB and OX as applied to the ovarian cancer A2780, $A 2780^{\text {cisR }}, A 2780^{Z D 0473 R}$ and SKOV-3 cell lines. $I_{50}$ is the drug concentration required for $50 \%$ cell kill and RF is the ratio of the $I C_{50}$ value in the resistant $A 2780^{\text {cisR }}$ and $A 2780^{\text {ZD0473R }}$ cell lines over that in the responsive parent $\mathrm{A} 2780$ cell line

\begin{tabular}{|c|c|c|c|c|c|c|}
\hline & A2780 & A2780 $0^{\text {cisR }}$ & RF & $\mathrm{A} 2780^{\mathrm{ZD} 0473 \mathrm{R}}$ & RF & SKOV-3 \\
\hline$\overline{\mathrm{CS}}$ & $0.5 \pm 0.03$ & $8.2 \pm 0.6$ & 17.7 & $6.0 \pm 0.5$ & 13.0 & $10.2 \pm 0.5$ \\
\hline$C B$ & $14.0 \pm 1.4$ & $48.9 \pm 3.9$ & 3.5 & $64.6 \pm 3.2$ & 4.6 & $43.4 \pm 3.9$ \\
\hline OX & $0.2 \pm 0.01$ & $0.4 \pm 0.02$ & 1.9 & $0.4 \pm 0.03$ & 2.1 & $43.6 \pm 3.0$ \\
\hline
\end{tabular}

When OX was administered in two aliquots (fresh/ aged), cell kill in A2780 cells was pronounced when the time gap was 4, 8 and $24 \mathrm{~h}$ and reduced cell kill was observed when the time gap was $2 \mathrm{~h}$. In $\mathrm{A} 2780^{\mathrm{cisR}}$ and $\mathrm{A} 2780^{\mathrm{ZD} 0473 \mathrm{R}}$, all the time gaps (especially 4 and $8 \mathrm{~h}$ ) produced pronounced cell kill. When OX was administered in two aliquots (fresh/aged) to SKOV-3 cell line, cell kill was pronounced when the time gap was $2 \mathrm{~h}$, additive when it was $4 \mathrm{~h}$ and reduced cell kill was observed when it was increased to 8 and $24 \mathrm{~h}$. The results indicate the administration of CS, CB, and OX in two aliquots, with the first aliquot fresh and the second aliquot aged, generally caused enhanced cell kill especially in the resistant $\mathrm{A} 2780^{\mathrm{cisR}}$ and $\mathrm{A} 2780^{\mathrm{ZD} 0473 \mathrm{R}}$ cell lines. In contrast, administration of $\mathrm{CS}, \mathrm{CB}$ and $\mathrm{OX}$ in two aliquots with both being fresh, produced mostly reduced cell kill in $\mathrm{A} 2780, \mathrm{~A} 2780^{\mathrm{cisR}}$ and $\mathrm{A} 2780^{\mathrm{ZD} 0473 \mathrm{R}}$ cell lines. In SKOV-3 cell line, enhanced cell kill resulted when the time gap was 2, 4, and $8 \mathrm{~h}$ and reduced cell kill resulted when it was $24 \mathrm{~h}$ (Fig. 3).

\section{Platinum accumulation}

To determine whether the enhanced cell kill was associated with an increase in platinum accumulation, the levels of platinum accumulation following the administration of CS in two aliquots with a time gap of 2 and $4 \mathrm{~h}$ in $\mathrm{A} 2780$ and $\mathrm{A} 2780^{\mathrm{cisR}}$ cell lines were determined, using both fresh and aged solutions (Fig. 4). It was found that both fresh/fresh and fresh/aged combinations were associated with significantly higher platinum accumulations in A2780 cell line. The highest platinum accumulation resulted from fresh/aged combination with $4 \mathrm{~h}$ time gap. In the resistant $\mathrm{A} 2780^{\text {cisR }}$ cell line, only the aged solution resulted in increased platinum accumulation.

\section{Platinum-DNA binding}

As a key step in the antitumour action of platinum drugs is their binding with DNA (that initiates downstream processes in the cell cycle leading to apoptosis), platinum - DNA binding levels in A2780 and A2780 ${ }^{\text {cisR }}$ cell lines were determined applying to administration of solutions of CS in two aliquots with a time gap of 2 and
4 h, using both fresh/fresh and fresh/aged combinations. Figure 2 gave platinum - DNA binding levels in ovarian cancer A2780 and A2780 ${ }^{\text {cisR }}$ cell lines as applied to the administration of CS in two aliquots with a time gap of 2 and $4 \mathrm{~h}$.

The platinum - DNA binding levels in A2780 cisR cell line were generally found to be greater from administration in two aliquots than from the bolus for both 2 and $4 \mathrm{~h}$ time gaps, as applied to both fresh/fresh and fresh/ aged combinations but more so for the latter. In the parent A2780 cell line, only the fresh/aged combination resulted in greater Pt - DNA binding level (for both 2 and 4 time gaps) than the bolus (Fig. 5).

\section{Cellular glutathione}

Since oxidative stress is like a double edged sword in cancer that can lead to both programmed cell death and cell survival, the effect of nature of administration of CS and $\mathrm{CB}$ on the cellular glutathione level was also investigated. Specifically, the effect of administration of the drug as a bolus and in two aliquots applying to both fresh/fresh and fresh/aged solutions of $\mathrm{CB}$ and CS was investigated. The levels of total glutathione (GSH plus GSSG) and the oxidized glutathione (GSSG) in A2780 and A2780 ${ }^{\text {cisR }}$ cell lines were determined (Fig. 6a, b). In line with reported result [13-15], total glutathione was found to be higher in the CS-resistant A2780 ${ }^{\text {cisR }}$ cell line than in the parent A2780 cell line before and after drug treatment. There was a significant decrease in total glutathione level following treatment of A2780 and A2780 ${ }^{\text {cisR }}$ cells with solutions of CS and CB. This was found to be true for both bolus administration and that in two aliquots but more so for the bolus. The results indicate that bolus administration of CS and CB produced a greater oxidative stress in the cells than that in two aliquots. As noted earlier, there was an increase in cell kill due to the administration of CS and $\mathrm{CB}$ in two aliquots using fresh/aged combinations.

\section{Platinum speciation}

With the idea that the greater cell kill resulting from administration of CS, CB and OX in two aliquots using fresh/aged combinations could be due to speciation of the drugs (resulting in the production of more cytotoxic species), mass spectral analysis of solutions of OX in cell culture media were performed. Figure 7 gave magnified mass spectrum showing major peaks of OX dissolved in cell culture medium. The major peaks observed in the mass spectra are given in Table 3.

Peak with $\mathrm{m} / \mathrm{z}=420.0493$ is believed to be due to the molecular ion $\left[\mathrm{Pt}(\mathrm{DACH})\left(\mathrm{C}_{2} \mathrm{O}_{4}\right)+\mathrm{Na}\right]^{+}$where $\mathrm{Na}^{+}$is from the culture media. Peak with $\mathrm{m} / \mathrm{z}=$ 436.0233 is believed to be due to the molecular ion $\left[\mathrm{Pt}(\mathrm{DACH})\left(\mathrm{C}_{2} \mathrm{O}_{4}\right)+\mathrm{K}\right]^{+}$where $\mathrm{K}^{+}$is from the culture media. Peak with $\mathrm{m} / \mathrm{z}=478.0080$ is due to $\mathrm{Pt}(\mathrm{DACH})(\mathrm{Pyr})$ 


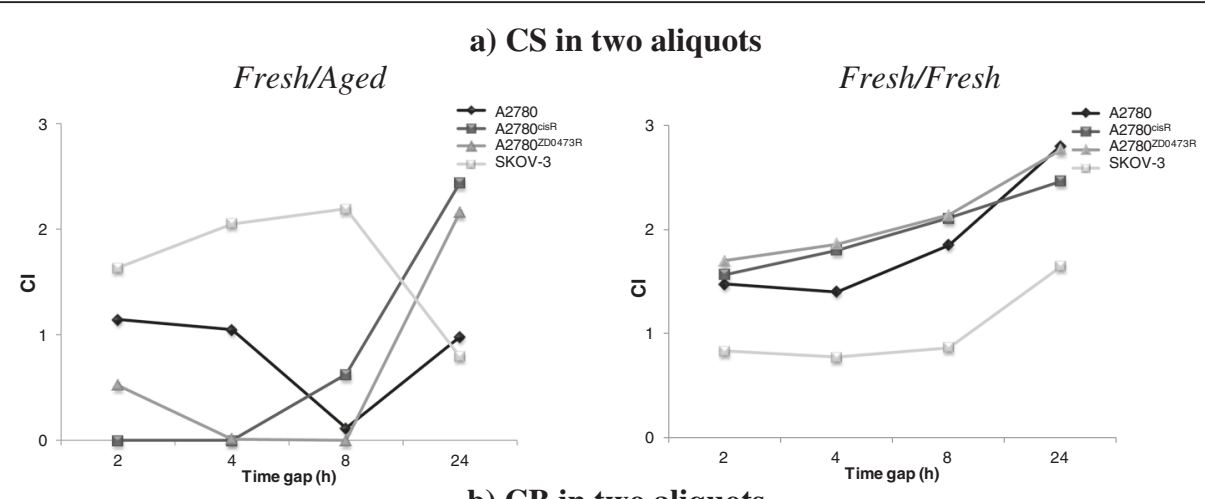

b) $\mathrm{CB}$ in two aliquots

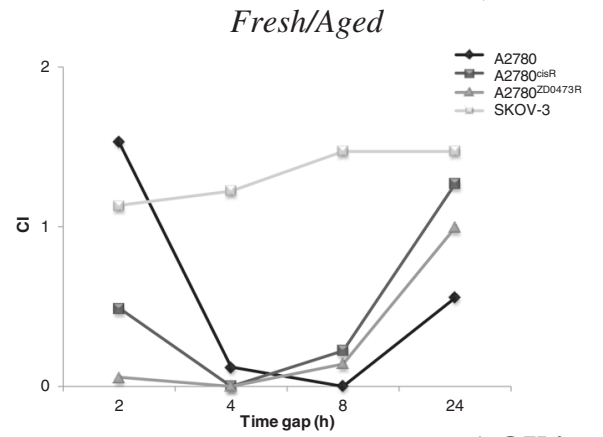

c) $\mathrm{OX}$ in two aliquots

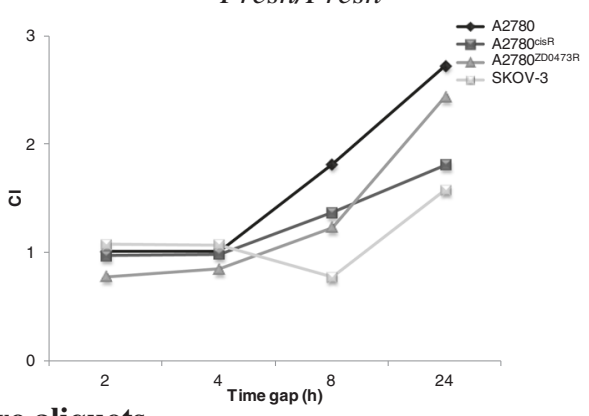

Fresh/Aged
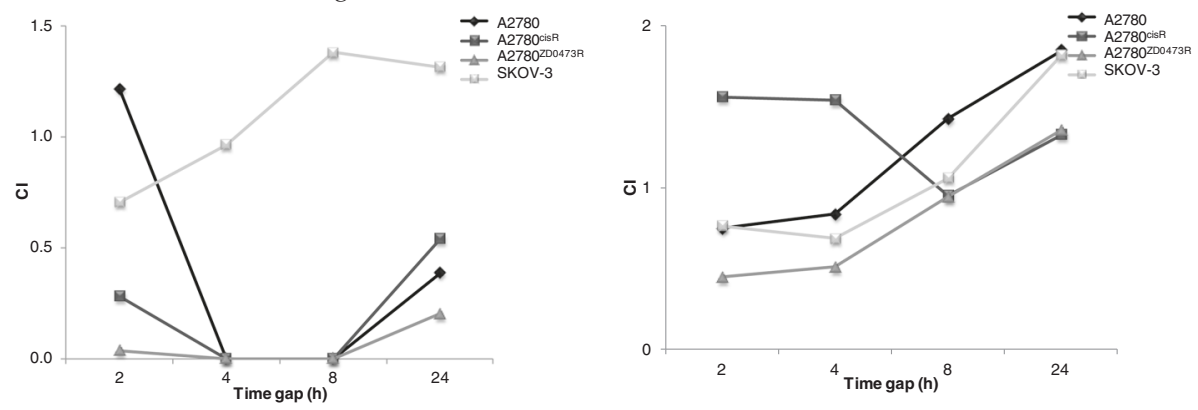

\section{CI $<1$ Synergistic \\ $\mathrm{CI}=1$ Additive \\ CI>1 Antagonistic}

Fig. 3 Combination Index (CI) values following the administration of $\mathbf{a} \mathrm{CS}, \mathbf{b}$ CB and $\mathbf{c}$ OX in two aliquots with a time gap of 2, 4, 8, or 24 h as applied to the ovarian cancer A2780, A2780 cisR , A2780 $2 \mathrm{DO473R}$ and SKOV-3 cell lines using both fresh/fresh and fresh/aged combinations. Cl values were calculated following $72 \mathrm{~h}$ treatments. $\mathrm{Cl}$ values of $<1,=1$ and $>1$ indicate respectively synergism, additivity and antagonism in combined drug action

(where Pyr $=$ pyridoxine $\left(\right.$ vitamin $\left.\mathrm{B}_{6}\right)$ ), believed to be formed in the cell culture media. The peak with $\mathrm{m} / \mathrm{z}=$ 680.1303 may be due to $\mathrm{Pt}(\mathrm{DACH})\left(\mathrm{SCH}_{3}\right)(\mathrm{GSH})$ formed in the culture media and that with $\mathrm{m} / \mathrm{z}=795.0480$ is believed to be due to dimeric species consisting of two $\mathrm{Pt}(\mathrm{DACH})$ units catenated by two oxalate ligands. Finally, the peak with $\mathrm{m} / \mathrm{z}=940.2129$ is believed to be due to $\mathrm{Pt}(\mathrm{DACH})(\mathrm{GSH})_{2}$.

\section{Proteomics}

As stated earlier, proteomic studies were carried out to identify the proteins differentially expressed in the resistant $\mathrm{A} 2780^{\mathrm{cisR}}$ cell line as compared to the levels found in parent A2780 cell line. 2-D gels resolved over 390 proteins of which 72 were found to be differentially expressed in A2780 $0^{\text {cisR }}$ cell line as compared to the parent A2780 cell line (Fig. 8). Administration of CS in two aliquots with a time gap was found to restore the expression of at least 22 proteins to the levels found in the parent cell line, of which 12 were down-regulated and 10 up-regulated prior to drug treatment. A summary of the proteins, their possible functions, and associations with neoplasia are given in Table 4 . The proteins belong to seven groups 


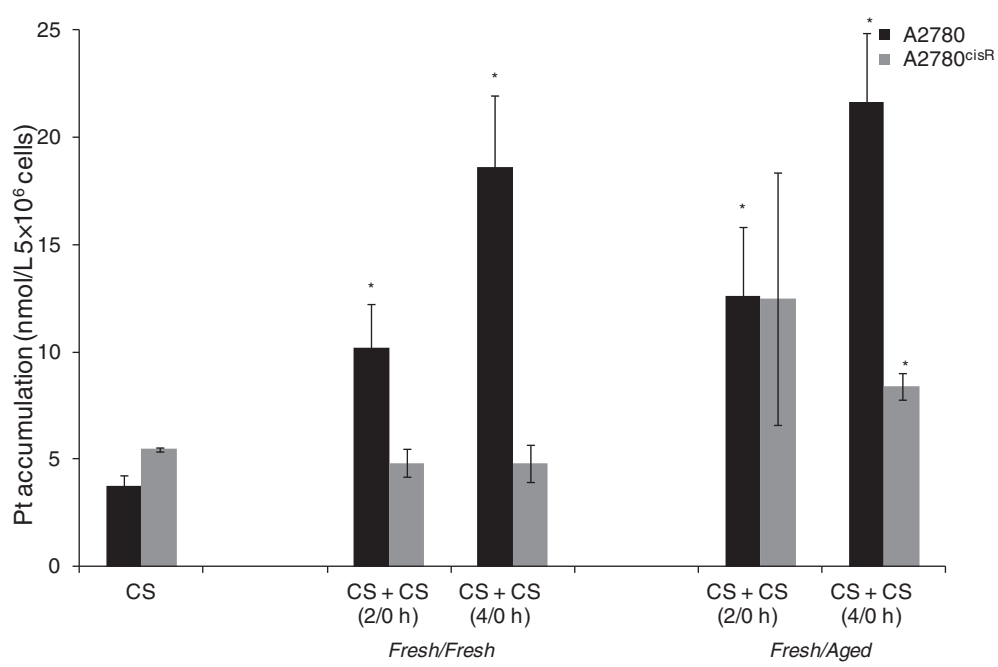

Fig. 4 Cellular platinum accumulation in ovarian cancer A2780 and A2780 $0^{\text {cisR }}$ cell lines resulting from administration of CS in two aliquots using both fresh/fresh and fresh/aged combinations of CS with a time gap of 2 and $4 \mathrm{~h}$. Cells were treated with the drugs for $24 \mathrm{~h}$ followed by collection, lysis and finally Pt was determined using AAS. Data was statistically analyzed using the paired Student's $t$ test: ${ }^{*} p<0.05$ indicates significant difference from control. Error bars represent the standard deviation

based on cellular functions namely: invasion and metastasis, cell cycle regulation and proliferation, metabolic and biosynthesis processes, stress-related proteins and chaperones, mRNA processing proteins, cellular organization/cytoskeleton, cellular communication and signal transduction (Fig. 9). The proteins are believed to be associated with platinum resistance in ovarian cancer. A more detailed description of their functions as applied to platinum resistance in ovarian cancer is given in the discussion.

\section{Discussion}

In this study, the efficacy of administering CS, CB and $\mathrm{OX}$ in two aliquots with a time gap was investigated

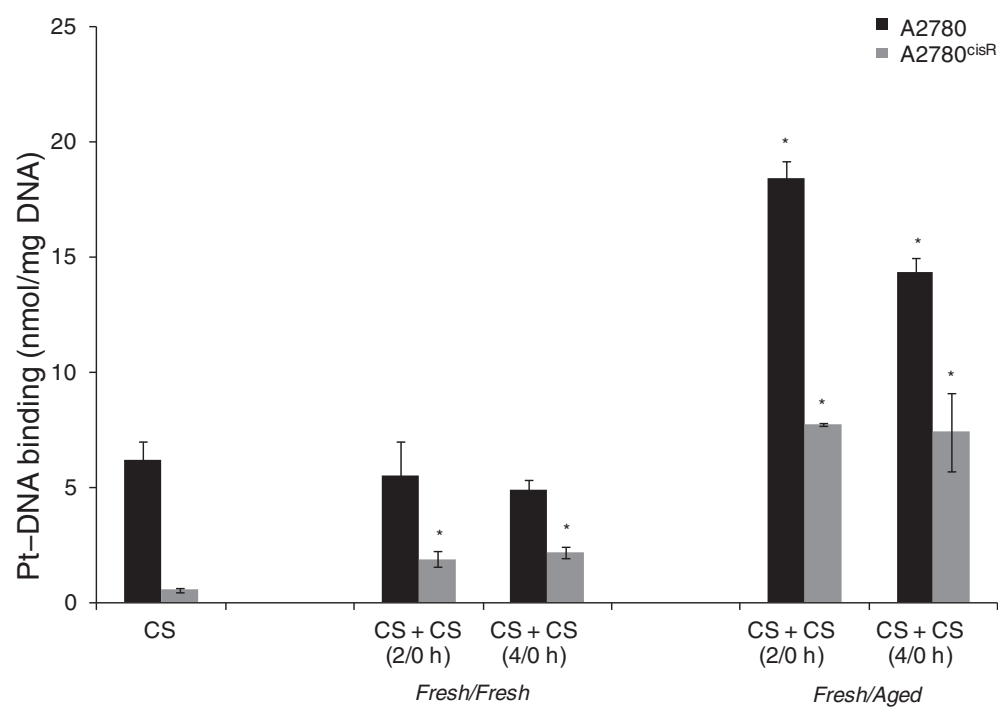

Fig. 5 Platinum - DNA binding in ovarian cancer A2780 and A2780 cisR cell lines as applied to the administration of CS in two aliquots using both fresh/fresh and fresh/aged combinations of CS with a time gap of 2 and $4 \mathrm{~h}$. Cells were treated with the drugs for $24 \mathrm{~h}$ followed by collection, DNA extraction and finally pt detection using AAS. Data was statistically analyzed using the paired Student's $t$ test: ${ }^{*} p<0.05$ indicates significant difference from control. Error bars represent the standard deviation 

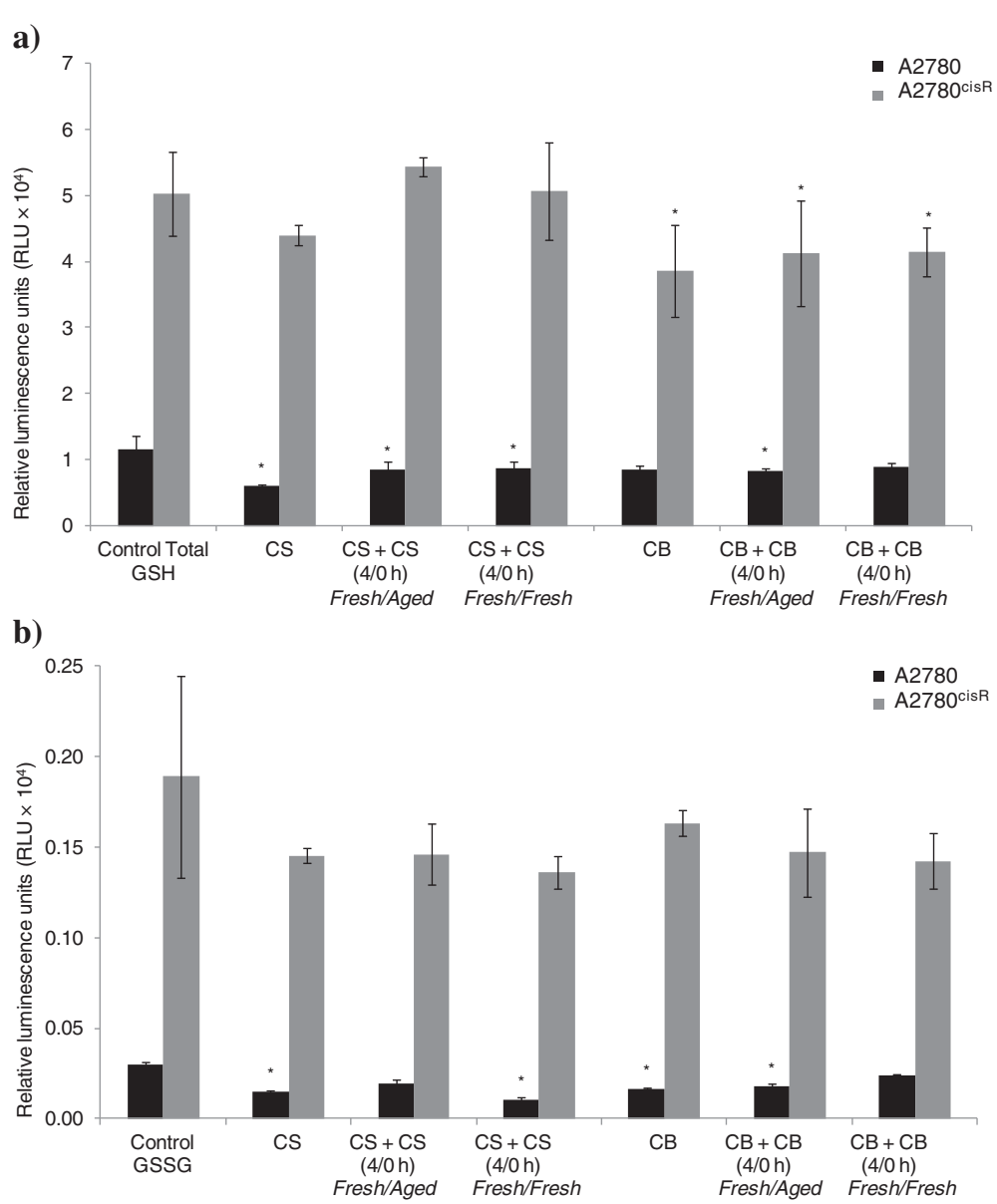

Fig. 6 Levels of a total glutathione (GSH plus GSSG) and b oxidized glutathione (GSSG) in relative luminescence units (RLU $\times 10^{4}$ ) in A2780 and $\mathrm{A} 2780^{\text {cisR }}$ cells before and after their treatments with solutions of CS and CB administered as a bolus and in two aliquots with time gaps of 2 and $4 \mathrm{~h}$ using fresh/fresh and fresh/aged combinations. Cells were treated for $24 \mathrm{~h}$ and glutathione content was determined using GSH/GSSG-Glo Assay kit. Data was statistically analyzed using the paired Student's $t$ test: ${ }^{*} p<0.05$ indicates significant difference from control. Error bars represent the standard deviation

with the idea that results may provide information about the processes that take place during platinum-based chemotherapy practiced in the clinic. In particular, the results might provide valuable insight into the molecular aspect of administering the same drug in cycles. As noted earlier [11], among the three platinum drugs, OX was most active against the ovarian cancer A2780, $\mathrm{A} 2780^{\mathrm{cisR}}$ and A2780 ${ }^{\mathrm{ZD} 0473 \mathrm{R}}$ cell lines but had the lowest activity against SKOV-3 cell line. The higher activity of $\mathrm{OX}$ as compared to CS against A2780, A2780 $0^{\text {cisR }}$ and A2780 ${ }^{\text {ZD0473R }}$ cell lines, could be due to differences in both the leaving groups and the carrier ligands in $\mathrm{OX}$ and CS (oxalate in OX as against chloride in CS and trans- $R, R$-diaminocyclohexane abbreviated as DACH in $\mathrm{OX}$ as against ammonia in CS). This difference allows several conformational differences to exist in the intrastrand 1,2-(GpG) adducts formed by CS and OX [16, 17]. Whereas the CS crosslink preferentially undergoes hydrogen bonding with the 5 ' side of adduct (that causes a greater structural distortion to the base pair at the $5^{\prime}$ end), OX does so with the 3 ' end of the intrastrand crosslink. Also, in the case of OX there is a strong hydrogen bond between the $\mathrm{NH}_{2}$ group of the $\mathrm{DACH}$ ligand and the $\mathrm{O} 6$ oxygen atom of the 3 ' guanine nucleobase. It has been suggested that the conformational differences between OX - DNA and CS - DNA adducts may be responsible for differences in their protein recognition and cellular processing [16]. The low activity of OX against SKOV-3 cell line may lie in the p53-null status of the cells $[18,19]$.

As applied to the administration of CS, CB and OX in two aliquots with a time gap, experiments were done using both fresh/fresh and fresh/aged solutions. The purpose behind using both fresh and aged solutions was to determine the effect of speciation of activity of platinum drugs. Hydrolysis of platinum drugs produces highly reactive mono- and di-aquo species that can deprotonate and polymerise to produce species with multiple metal 


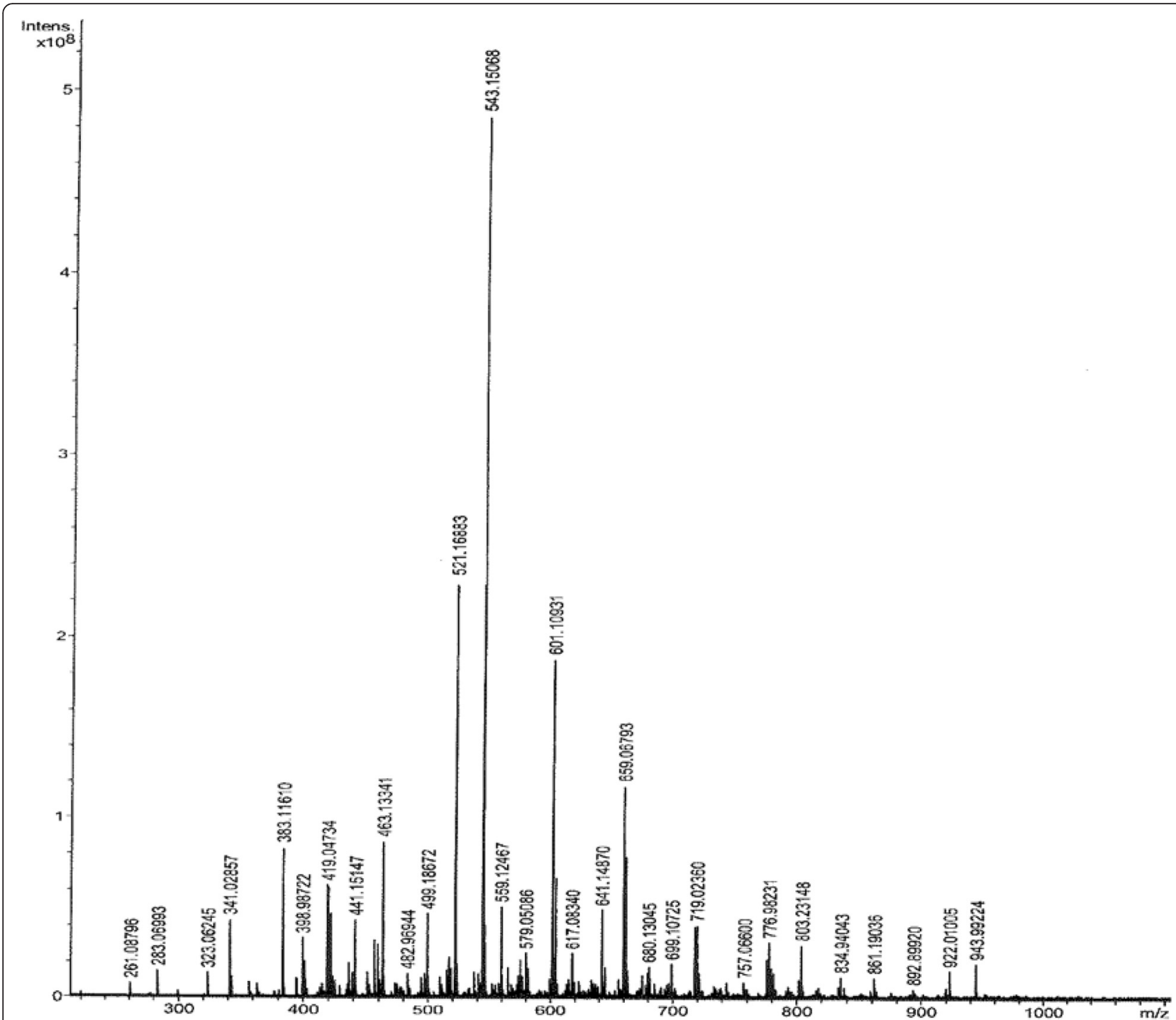

Fig. 7 Magnified mass spectrum showing major peaks of OX dissolved in cell culture medium. The 543.1 peak is the base peak due to the cell culture medium

centres. The presence of the species is believed to alter the nature of interaction with DNA (as well as that with other cellular platinophiles). For example, multi-nuclear platinum species may carry a greater net positive charge making them more easily attracted to the negatively charged DNA. Furthermore, unlike CS that binds predominantly to one strand of DNA, multinuclear species may bind more significantly to both the strands of DNA $[20,21]$.

When CS, CB and OX were administered in two aliquots with a time gap than as a bolus, it was found that there was a greater cell kill with fresh/aged combination. The extent of cell kill was dependent on the duration of the time gap with $8 \mathrm{~h}$ time gap producing most pronounced cell kill in the parent A2780 cell line. In $\mathrm{A} 2780^{\mathrm{cisR}}$ and $\mathrm{A} 2780^{\mathrm{ZD} 0473 \mathrm{R}}$ resistant cell lines, time gaps of 2, 4, and $8 \mathrm{~h}$ all caused pronounced cell death. In contrast, in SKOV-3 cell line, $24 \mathrm{~h}$ time gap was additive in action whereas 2 to $8 \mathrm{~h}$ time gaps were antagonistic. Additiveness to antagonism observed with fresh/fresh combinations and synergism seen with fresh/aged combinations, suggest that the increased cell kill associated with the latter may be due to the formation of more cytotoxic species resulting from hydrolysis, deprotonation and polymerisation reactions and the rates of these processes are considered to be greater at the ambient temperature than under the frozen condition. In line with the idea, it was found that when solutions of CS were left standing at room temperature, the cell killing effect increased with time (data not shown) as was observed by others (Yachnin [21]). To gain a better understanding of the speciation of platinum drugs in solution 
Table 3 Major peaks in the mass spectra of aged solution of OX in cell media

\begin{tabular}{|c|c|c|c|c|}
\hline $\mathrm{m} / \mathrm{z}$ & No. of possibilities & Formula & Relative intensity $\left(\times 10^{6}\right)$ & Suggested structure \\
\hline 398 & 1 & $\mathrm{Pt}\left(\mathrm{C}_{6} \mathrm{H}_{14} \mathrm{~N}_{2}\right)\left(\mathrm{C}_{2} \mathrm{O}_{4}\right)$ & 16 & \\
\hline 420.0493 & 4 & {$\left[\mathrm{Pt}\left(\mathrm{C}_{6} \mathrm{H}_{14} \mathrm{~N}_{2}\right)\left(\mathrm{C}_{2} \mathrm{O}_{4}\right)+\mathrm{Na}\right]^{+}$} & 4.6 & \\
\hline 436.0233 & 2 & $\mathrm{Pt}\left(\mathrm{C}_{6} \mathrm{H}_{14} \mathrm{~N}_{2}\right)_{2}-3 \mathrm{H}$ & 7.2 & \\
\hline 478.0080 & 14 & {$\left[\mathrm{Pt}\left(\mathrm{C}_{6} \mathrm{H}_{14} \mathrm{~N}_{2}\right)\left(\mathrm{C}_{8} \mathrm{H}_{11} \mathrm{NO}_{3}\right)\right]^{+}$} & 8 & \\
\hline 680.1303 & 67 & {$\left[\mathrm{Pt}\left(\mathrm{C}_{6} \mathrm{H}_{14} \mathrm{~N}_{2}\right)\left(\mathrm{C}_{10} \mathrm{H}_{17} \mathrm{~N}_{3} \mathrm{O}_{6} \mathrm{~S}\right)\left(\mathrm{CH}_{3} \mathrm{CH}_{2} \mathrm{SH}\right)+2 \mathrm{H}\right]^{+}$} & 26 & \\
\hline 738.0889 & 157 & {$\left[\mathrm{Pt}\left(\mathrm{C}_{6} \mathrm{H}_{14} \mathrm{~N}_{2}\right)\left(\mathrm{C}_{10} \mathrm{H}_{17} \mathrm{~N}_{3} \mathrm{O}_{6} \mathrm{~S}\right)\left(\mathrm{C}_{3} \mathrm{H}_{7} \mathrm{NO}_{2} \mathrm{~S}\right)\right]^{+}$} & 9 & \\
\hline 795.0480 & 277 & {$\left[\mathrm{Pt}_{2}\left(\mathrm{C}_{6} \mathrm{H}_{14} \mathrm{~N}_{2}\right)_{2}\left(\mathrm{C}_{2} \mathrm{O}_{4}\right)_{2}+\mathrm{H}\right]^{+}$} & 21 & \\
\hline 940.2129 & 377 & {$\left[\mathrm{Pt}\left(\mathrm{C}_{6} \mathrm{H}_{14} \mathrm{~N}_{2}\right)\left(\mathrm{C}_{10} \mathrm{H}_{17} \mathrm{~N}_{3} \mathrm{O}_{6} \mathrm{~S}\right)_{2} \mathrm{O}\right]^{+}$} & 19 & \\
\hline
\end{tabular}

in terms of hydrolysis and formation of more cytotoxic species, limited mass spectral measurements with solutions of OX were carried out. The results are discussed latter in the paper.

Also whether the enhanced cell kill due to the administration of platinum drugs in two aliquots with a time gap was associated with a corresponding increase in cellular accumulation of platinum and consequently a greater level of platinum - DNA binding or it was due to speciation of platinum drugs in cell culture medium at the ambient temperature, the cellular platinum accumulation and platinum - DNA binding levels associated with the administration of CS in two aliquots with a time gap (2 and $4 \mathrm{~h})$ were determined, as applied to both fresh/fresh and fresh/ 


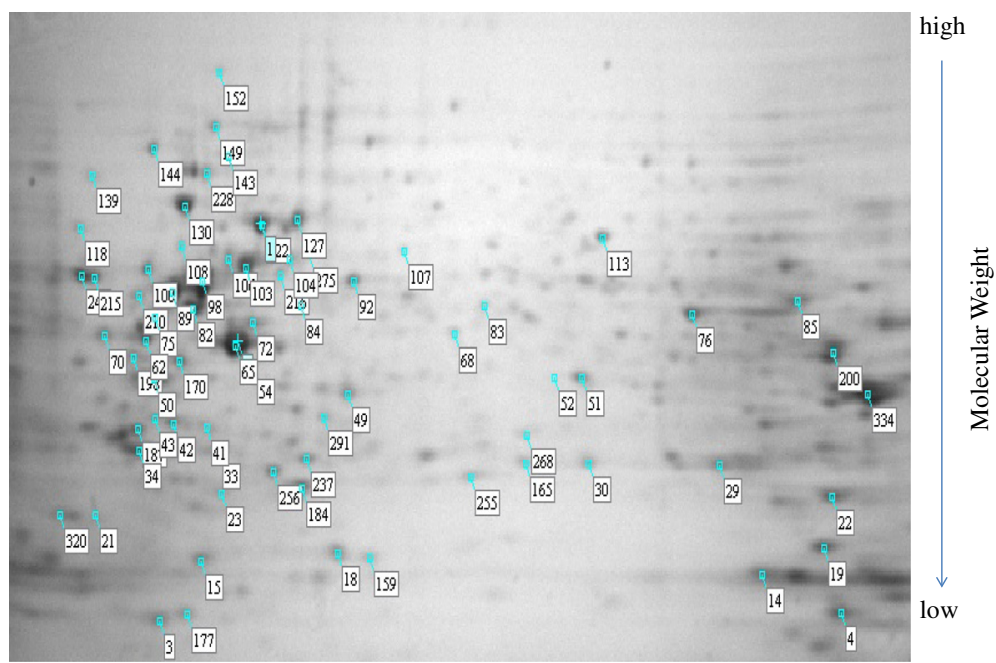

Fig. 8 2-DE pattern of whole-cell proteins in A2780 cell line. The 2-D gel was stained with coomasiee brilliant blue (11 cm, pH 3-10 non-linear, 4-20\% SDS-PAGE, $200 \mu \mathrm{g}$ proteins). The protein spots differentially expressed in A2780 cisR compared to the parent A2780 cell line identified in this study are marked with their spot number ID

aged combinations. It may be noted that although platinum-DNA binding is a necessary step in the programmed cell death due to platinum drugs, it is not sufficient as the programmed cell death is actually carried out by downstream processes in the cell cycle in which many proteins are involved. In any case, the drugs must enter the cells before they can bind with DNA or be deactivated due to binding with cellular platinophiles [3, 22].

Figures 4 and 5 gave the cellular accumulation and platinum - DNA binding levels resulting from administration of CS in two aliquots with time gaps of 2 and $4 \mathrm{~h}$ in A2780 and A2780 ${ }^{\mathrm{cisR}}$ cells, as applied to both fresh/ fresh and fresh/aged combinations. It was found that fresh/aged combination produced greater platinum accumulation than the fresh/fresh combination suggesting that there were either greater influx or reduced efflux or both. Since the species formed are likely to be positively charged, they are more likely to be transported by organic cationic transporters rather than by passive diffusion and copper transporter 1 that is also known to transport CS into the cell (CTR1) [23]. As applied to platinum - DNA binding level, it was found that in the parent A2780 cell line administration in two aliquots with a time gap resulted in a lower platinum-DNA binding level with fresh/fresh combination than the bolus but a greater level from fresh/aged combination. In the CS-resistant $\mathrm{A} 2780^{\text {cisR }}$ cell line, both fresh/fresh and fresh/aged combinations resulted in significantly greater platinum-DNA binding levels than the bolus. The results indicate that (regardless of the ageing status of the solution) the administration of platinum drugs in two aliquots with a time gap may be better able to overcome mechanism of platinum resistance in the CSresistant cell line, giving support to the merit of cycle regimens used in the clinic.

Cellular glutathione levels were also determined as a measure of changes in redox status of the cell. Figure $6 a$ and $\mathrm{b}$ respectively gave the levels of total glutathione (GSH and GSSG) and oxidized glutathione (GSSG) in $\mathrm{A} 2780$ and $\mathrm{A} 2780^{\mathrm{cisR}}$ cell lines following their treatments with solutions of CS and CB administered as a bolus and in two aliquots with a $4 \mathrm{~h}$ time gap. Although the level of total glutathione in both A2780 and A2780 ${ }^{\text {cisR }}$ cell lines after drug treatments was lower than the levels before treatment (irrespective of whether the drug was administered as a bolus or in two aliquots), the decrease was greater for the bolus than the administrations in two aliquots. $\mathrm{CB}$ was found to be more effective than CS in lowering the level of GSH in the CS-resistant A2780 ${ }^{\text {cisR }}$ cell line although a kinetic study suggested that rates of reaction CS and OX with GSH were 5-fold greater than that of $\mathrm{CB}$ [24].

A smaller decrease in GSH level observed in both $\mathrm{A} 2780$ and $\mathrm{A} 2780^{\text {cisR }}$ cells after treatment with CS and $\mathrm{CB}$ given as a bolus than in two aliquots (with a time gap), rebuts the hypothesis that the first aliquot would decrease glutathione level enabling more of the second aliquot of platinum to bind to DNA. This means that the greater cell kill resulting from administration of platinum drugs in two aliquots with a time gap can be due to speciation of platinum drugs rather than changes in cellular glutathione level. Thus, other changes such as differential expression of proteins may be responsible for 
Table 4 In total, 22 proteins with differential expression (2-fold increase or decrease, ANOVA $p<0.05$ ) between A2780 cisR and the parent A2780 cell line due to treatment with $\mathrm{CS}$ in two aliquots with a time gap of $2 \mathrm{~h}$ using fresh/fresh and fresh/aged combinations were identified by MALDI-TOF/TOF

\begin{tabular}{|c|c|c|c|c|c|c|c|c|c|c|}
\hline \multirow[t]{3}{*}{ Spot } & \multirow[t]{3}{*}{ ID } & \multirow[t]{3}{*}{ Full name } & \multirow[t]{3}{*}{ MALDI } & \multirow[t]{3}{*}{ location } & \multirow[t]{3}{*}{$\begin{array}{l}\text { Expression in } \\
\text { A2780 }\end{array}$} & \multicolumn{3}{|c|}{$\begin{array}{l}\text { Post treatment } \\
\text { expression }\end{array}$} & \multirow[t]{3}{*}{ Function } & \multirow[t]{3}{*}{ Tumour association } \\
\hline & & & & & & \multirow[t]{2}{*}{ CS } & \multicolumn{2}{|c|}{$\mathrm{CS}+\mathrm{CS}$} & & \\
\hline & & & & & & & fresh & aged & & \\
\hline 3 & COX5A & $\begin{array}{l}\text { Cytochrome c oxidase } \\
\text { subunit } 5 \mathrm{~A} \text {, mitochondrial }\end{array}$ & $\begin{array}{l}\text { Score: } 63 \\
\text { Mass: } 16752 \\
\text { pl: } 6.30 \\
\text { Coverage: } 11 \%\end{array}$ & Mitochondria & Down Regulated & $P R$ & $P R$ & OR & $\begin{array}{l}\text { Ribosome biogenesis; } \\
\text { mitochondrial respiratory } \\
\text { chain }\end{array}$ & $\begin{array}{l}\text { Breast [77]; cervix [78]; colon [77]; } \\
\text { gastric [31]; Kidney [79]; Lung [80-82]; } \\
\text { Nasopharyngeal [32]; Oesophageal [77]; } \\
\text { Ovarian [77]; Prostate [77]; Thyroid [83] }\end{array}$ \\
\hline 19 & COF2 & Cofilin-2 & $\begin{array}{l}\text { Score: } 127 \\
\text { Mass: } 18725 \\
\text { pl: } 7.66 \\
\text { Coverage: } 39 \%\end{array}$ & $\begin{array}{l}\text { Cytoplasm, } \\
\text { cytoskeleton }\end{array}$ & Down Regulated & $\mathrm{R}$ & $\mathrm{R}$ & OR & Actin polymerization & Pancreatic [84]; Prostate [85] \\
\hline 34 & $1433 G$ & $14-3-3$ protein gamma & $\begin{array}{l}\text { Score: } 315 \\
\text { Mass: } 28285 \\
\text { pl: } 4.80 \\
\text { Coverage: } 44 \%\end{array}$ & Cytoplasm & Down Regulated & $P R$ & $P R$ & OR & Adapter protein & Breast [86] \\
\hline 41 & MARE1 & $\begin{array}{l}\text { Microtubule-associated } \\
\text { protein RP/EB family } \\
\text { member } 1\end{array}$ & $\begin{array}{l}\text { Score: } 62 \\
\text { Mass: } 29980 \\
\text { pl: } 5.02 \\
\text { Coverage: } 29 \%\end{array}$ & Cytoplasm & Down Regulated & - & $\mathrm{R}$ & OR & $\begin{array}{l}\text { Microtubule cytoskeleton } \\
\text { dynamics; cell migration. }\end{array}$ & $\begin{array}{l}\text { Colon [87]; lung [88]; gastric [89]; } \\
\text { oesophageal [90]; }\end{array}$ \\
\hline 50 & NPM & Nucleophosmin & $\begin{array}{l}\text { Score: } 68 \\
\text { Mass: } 32555 \\
\text { pl: } 4.64 \\
\text { Coverage: } 26 \%\end{array}$ & Nucleoplasm & Down Regulated & - & $\mathrm{R}$ & OR & $\begin{array}{l}\text { Chaperone; ribosome } \\
\text { biogenesis; p53 and ARF } \\
\text { regulation }\end{array}$ & $\begin{array}{l}\text { Bladder [91]; breast [92]; Colon [93]; } \\
\text { gastric [94]; haematopoietic [40]; } \\
\text { ovarian [95]; prostate [96] }\end{array}$ \\
\hline 51 & ANXA1 & Annexin A1 & $\begin{array}{l}\text { Score: } 369 \\
\text { Mass: } 38690 \\
\text { pl: } 6.57 \\
\text { Coverage: } 53 \%\end{array}$ & Nucleus, cytoplasm & Down Regulated & $\mathrm{R}$ & $\mathrm{R}$ & OR & $\begin{array}{l}\text { Calcium/phospholipid- } \\
\text { binding protein }\end{array}$ & $\begin{array}{l}\text { breast [97]; gastric [98]; HNSC [36]; } \\
\text { lung [99]; oesophageal }[100,101] ; \\
\text { prostate }[100,102] ;\end{array}$ \\
\hline 62 & RSSA & $\begin{array}{l}40 S \text { ribosomal } \\
\text { protein SA }\end{array}$ & $\begin{array}{l}\text { Score: } 311 \\
\text { Mass: } 32833 \\
\text { pl: } 4.79 \\
\text { Coverage: } 34 \%\end{array}$ & $\begin{array}{l}\text { Cell membrane, } \\
\text { cytoplasm, nucleus }\end{array}$ & Up Regulated & R & $\mathrm{R}$ & - & $\begin{array}{l}\text { laminin receptor; fate } \\
\text { determination; tissue } \\
\text { morphogenesis }\end{array}$ & $\begin{array}{l}\text { Breast [103]; cervical [104]; colon } \\
{[54,55,105] \text {; melanoma [106] }}\end{array}$ \\
\hline 65 & ACTB & Actin, cytoplasmic 1 & $\begin{array}{l}\text { Score: } 767 \\
\text { Mass: } 41710 \\
\text { pl: } 5.29 \\
\text { Coverage: } 53 \%\end{array}$ & Cytoplasm & Up Regulated & $P R$ & $\mathrm{R}$ & $P R$ & cell motility & $\begin{array}{l}\text { Colon [107]; gastric [108]; liver [109]; } \\
\text { sarcoma [110] }\end{array}$ \\
\hline 70 & CALU & Calumenin & $\begin{array}{l}\text { Score: } 141 \\
\text { Mass: } 37084 \\
\text { pl: } 4.47 \\
\text { Coverage: } 14 \%\end{array}$ & $\begin{array}{l}\text { Sarcoplasmic, } \\
\text { endoplasmic reticulum }\end{array}$ & Up Regulated & - & OR & $P R$ & $\begin{array}{l}\text { Vitamin K-dependent } \\
\text { carboxylation }\end{array}$ & $\begin{array}{l}\text { Colon [111]; gastric [112]; glioblastoma } \\
\text { [113]; prostate [114]; }\end{array}$ \\
\hline 72 & HNRPF & $\begin{array}{l}\text { Heterogeneous nuclear } \\
\text { ribonucleoprotein F }\end{array}$ & $\begin{array}{l}\text { Score: } 342 \\
\text { Mass: } 45643 \\
\text { pl: } 5.38\end{array}$ & Nucleus & Down Regulated & $\mathrm{R}$ & OR & $\mathrm{R}$ & $\begin{array}{l}\text { processing of pre-mRNAs; } \\
\text { alternative splicing events }\end{array}$ & Gastric [115]; thyroid [116] \\
\hline
\end{tabular}


Table 4 In total, 22 proteins with differential expression (2-fold increase or decrease, ANOVA $p<0.05$ ) between A2780 cisR and the parent A2780 cell line due to treatment with $\mathrm{CS}$ in two aliquots with a time gap of $2 \mathrm{~h}$ using fresh/fresh and fresh/aged combinations were identified by MALDI-TOF/TOF (Continued)

\begin{tabular}{|c|c|c|c|c|c|c|c|c|c|c|}
\hline 76 & ENOA & Alpha-enolase & $\begin{array}{l}\text { Score: } 471 \\
\text { Mass: } 47139 \\
\text { pl: } 7.01 \\
\text { Coverage: } 47 \%\end{array}$ & Cytoplasm & Down Regulated & - & $P R$ & $\mathrm{R}$ & $\begin{array}{l}\text { Glycolysis; hypoxia tolerance; } \\
\text { tumour suppressor }\end{array}$ & $\begin{array}{l}\text { Breast [117]; lung [118]; } \\
\text { nasopharyngeal [119]; }\end{array}$ \\
\hline 85 & ATPA & $\begin{array}{l}\text { ATP synthase subunit } \\
\text { alpha, mitochondrial }\end{array}$ & $\begin{array}{l}\text { Score: } 391 \\
\text { Mass: } 59714 \\
\text { pl: } 9.16 \\
\text { Coverage: } 29 \%\end{array}$ & Mitochondria & Up Regulated & - & OR & OR & Production of ATP from ADP & $\begin{array}{l}\text { Breast [120]; colon [121]; gastric [122]; } \\
\text { leukemia [123]; thyroid [124]; }\end{array}$ \\
\hline 92 & PDIA3 & $\begin{array}{l}\text { Protein disulfide- } \\
\text { isomerase A3 }\end{array}$ & $\begin{array}{l}\text { Score: } 525 \\
\text { Mass: } 56747 \\
\text { pl: } 5.98 \\
\text { Coverage: } 54 \%\end{array}$ & Endoplasmic reticulum & Down Regulated & $P R$ & PR & $\mathrm{R}$ & $\begin{array}{l}\text { endopeptidase; electron } \\
\text { carrier; }\end{array}$ & $\begin{array}{l}\text { Lung [125]; ovarian [48]; Prostate [46]; } \\
\text { retinoblastoma [126] }\end{array}$ \\
\hline 100 & HNRPK & $\begin{array}{l}\text { Heterogeneous nuclear } \\
\text { ribonucleoprotein K }\end{array}$ & $\begin{array}{l}\text { Score: } 123 \\
\text { Mass: } 50944 \\
\text { pl: } 5.39 \\
\text { Coverage: } 26 \%\end{array}$ & Cytoplasm, nucleus & Up Regulated & - & OR & - & $\begin{array}{l}\text { Pre-mRNA-binding proteins; } \\
\text { p53 response to DNA } \\
\text { damage }\end{array}$ & $\begin{array}{l}\text { Breast [127]; colon [128]; Leukemia } \\
\text { [129, 130]; lung [131]; Oropharyngeal } \\
\text { [132]; pancreatic [133]; }\end{array}$ \\
\hline 103 & $\mathrm{CH} 60$ & $\begin{array}{l}60 \mathrm{kDa} \text { heat shock } \\
\text { protein, mitochondrial }\end{array}$ & $\begin{array}{l}\text { Score: } 762 \\
\text { Mass: } 61016 \\
\text { pl: } 5.70 \\
\text { Coverage: } 39 \%\end{array}$ & Mitochondria & Up Regulated & $P R$ & OR & $P R$ & $\begin{array}{l}\text { macromolecular assembly; } \\
\text { stress working chaperone }\end{array}$ & $\begin{array}{l}\text { Bronchus [134]; Colon [135]; leukemia } \\
\text { [136]; prostate [137] }\end{array}$ \\
\hline 104 & $\mathrm{TCPQ}$ & $\begin{array}{l}\text { T-complex protein } 1 \\
\text { subunit theta }\end{array}$ & $\begin{array}{l}\text { Score: } 200 \\
\text { Mass: } 59583 \\
\text { pl: } 5.42 \\
\text { Coverage: } 24 \%\end{array}$ & Cytoplasm & Down Regulated & $\mathrm{R}$ & OR & $\mathrm{R}$ & chaperone & Colon [138]; liver [139]; \\
\hline 127 & GRP75 & $\begin{array}{l}\text { Stress-70 protein, } \\
\text { mitochondrial }\end{array}$ & $\begin{array}{l}\text { Score: } 839 \\
\text { Mass: } 73635 \\
\text { pl: } 5.87 \\
\text { Coverage: } 33 \%\end{array}$ & Mitochondria, nucleus & Down Regulated & $\mathrm{R}$ & $P R$ & $\mathrm{R}$ & $\begin{array}{l}\text { Cell proliferation; cellular } \\
\text { aging; chaperone }\end{array}$ & $\begin{array}{l}\text { Brain, Breast, colon, kidney, lung, } \\
\text { ovarian [140] }\end{array}$ \\
\hline 139 & GLU2B & $\begin{array}{l}\text { Glucosidase } 2 \text { subunit } \\
\text { beta }\end{array}$ & $\begin{array}{l}\text { Score: } 80 \\
\text { Mass: } 59388 \\
\text { pl: } 4.33 \\
\text { Coverage: } 11 \%\end{array}$ & Endoplasmic reticulum & Up Regulated & OR & OR & - & $\begin{array}{l}\text { Regulatory subunit of } \\
\text { glucosidase II }\end{array}$ & Colon $[138,141]$; sarcoma [142]; \\
\hline 149 & HSP74 & $\begin{array}{l}\text { Stress-70 protein, } \\
\text { mitochondrial }\end{array}$ & $\begin{array}{l}\text { Score: } 187 \\
\text { Mass: } 94271 \\
\text { pl: } 5.11 \\
\text { Coverage: } 10 \%\end{array}$ & Cytoplasm & Down Regulated & - & OR & $P R$ & $\begin{array}{l}\text { Stress response; cell } \\
\text { proliferation, differentiation }\end{array}$ & Breast [143] \\
\hline 170 & HNRPC & $\begin{array}{l}\text { Heterogeneous nuclear } \\
\text { ribonucleoproteins }\end{array}$ & $\begin{array}{l}\text { Score: } 142 \\
\text { Mass: } 33650 \\
\text { pl: } 4.95 \\
\text { Coverage. } 8 \%\end{array}$ & Nucleus & Up Regulated & - & $\mathrm{R}$ & OR & $\begin{array}{l}\text { mRNA processing and } \\
\text { translation }\end{array}$ & $\begin{array}{l}\text { Breast [144]; colon [145]; lung [146]; } \\
\text { pancreatic [147]; }\end{array}$ \\
\hline
\end{tabular}


Table 4 In total, 22 proteins with differential expression (2-fold increase or decrease, ANOVA $p<0.05$ ) between A2780 cisR and the parent A2780 cell line due to treatment with $\mathrm{CS}$ in two aliquots with a time gap of $2 \mathrm{~h}$ using fresh/fresh and fresh/aged combinations were identified by MALDI-TOF/TOF (Continued)

\begin{tabular}{|c|c|c|c|c|c|c|c|c|c|c|}
\hline 215 & CALR & Calreticulin & $\begin{array}{l}\text { Score: } 246 \\
\text { Mass: } 48112 \\
\text { pl: } 4.29 \\
\text { Coverage: } 17 \%\end{array}$ & $\begin{array}{l}\text { Endoplasmic, } \\
\text { sarcoplasmic reticulum }\end{array}$ & Up Regulated & - & $R$ & OR & $\begin{array}{l}\text { Calcium-binding } \\
\text { chaperone }\end{array}$ & $\begin{array}{l}\text { Bladder [69]; breast [148]; colon [149]; } \\
\text { gastric [150]; glioblastoma [69]; liver } \\
\text { [151]; ovarian [69]; pancreas [152]; } \\
\text { prostate [153] }\end{array}$ \\
\hline 246 & VIME & Vimentin & $\begin{array}{l}\text { Score: } 539 \\
\text { Mass: } 53619 \\
\text { pl: } 5.06 \\
\text { Coverage: } 81 \%\end{array}$ & Cytoplasm & Up Regulated & $P$ & OR & - & $\begin{array}{l}\text { Filaments attached to } \\
\text { nucleus and endoplasmic } \\
\text { reticulum }\end{array}$ & $\begin{array}{l}\text { Breast [154]; gastric [155]; lung [156]; } \\
\text { pancreas [157] }\end{array}$ \\
\hline
\end{tabular}

$(-)$ indicates that the spot was either not visible on the gel or that the treatment had no effect on the expression of the protein

$R$ Restored, $P R$ Partially Restored, OR Over Restored 


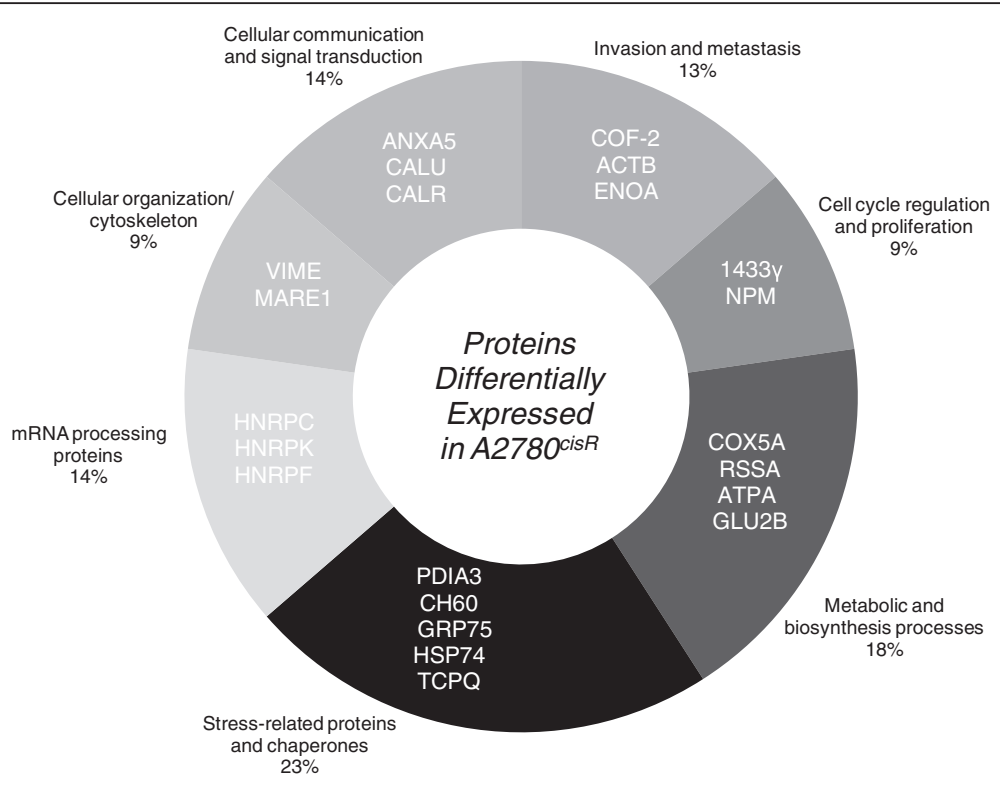

Fig. 9 Grouping of proteins and enzymes based on the cellular functions that were found to be differentially expressed in the resistant $A 2780^{c i s R}$ cell line as compared to the parent A2780 cell line and that have undergone further changes in expression after treatment with the administration of CS in two aliquots

enhanced cell kill. The level of oxidised glutathione (GSSG) is also found to decrease following treatment of cells with CS and CB suggesting enhanced efflux of conjugated products through MRPs.

Although in this study the mass spectral analysis of platinum speciation has been attempted primarily to find out about speciation of platinums on ageing i.e. when left standing at ambient temperature, it is important to note that platinum speciation especially in solution in the biological matrix gained increasing focus when it became clear that (1) the active drugs were the hydrolysed products rather than the intact molecules and that (2) the drugs are inactivated due to conjugation with proteins and peptides (such as glutathione) [25]. When solutions of OX made in buffered cell culture media were left standing at room temperature, a number of peaks were observed indicating that $\mathrm{OX}$ in solution underwent hydrolysis followed by further speciation. It should however be noted that many possible matches in terms of structure could be found for a given peak in the mass spectrum (having defined mass to charge ratio, mass error of less than $2 \mathrm{ppm}$ and isotopic splitting pattern). For example the peak with $\mathrm{m} / \mathrm{z}=420$ had four possible matches whereas that with $\mathrm{m} / \mathrm{z}=940$ had 377 matches. Notwithstanding the multitudes of structural possibilities for the observed peaks, it can be seen that OX in solution had underwent hydrolysis and that the products of hydrolysis conjugated with components present in the cell culture media. A detailed description of the peaks in terms of suggested structures is given as follows. It should be noted when the drug enters the cell, other compounds are likely to be formed due to binding with the cellular constituents. For example, formation of inactive complexes such as $\mathrm{Pt}(\mathrm{DACH})(\mathrm{GSH})$, $\mathrm{Pt}(\mathrm{DACH})(\mathrm{Cys})$ and $\mathrm{Pt}(\mathrm{DACH})(\mathrm{Met})$ due to binding of the $\mathrm{Pt}(\mathrm{DACH})$ unit with cellular constituents $\mathrm{GSH}$, Cys and methaionine (Met) have been reported [26]. The adducts may be inactive if they are inert towards binding with DNA. However, formation of such adducts within the cell may lead to oxidative stress and the resulting side effects due to depletion of cellular thiols [27]. A more definitive statement about the cytotoxicity of adducts can be made when they are isolated using a suitable method of separation e.g. reverse phase HPLC. It is possible that dimeric species $\mathrm{Pt}_{2}\left(\mathrm{C}_{6} \mathrm{H}_{14} \mathrm{~N}_{2}\right)_{2}\left(\mathrm{C}_{2} \mathrm{O}_{4}\right)_{2}$ can be a potent DNA binder with enhanced cytotoxicity. It is appropriate to note that many more dimeric and trimeric species were formed in the aged solution of $\mathrm{OX}$ in $\mathrm{mQ}$ water i.e. in the absence of culture media than in its presence. One important difference between speciation of OX in the buffered cell culture media and in solution in $\mathrm{mQ}$ water was that a greater number of hydrolysed products e.g. hydroxy, aqua and oxalate bridged dimeric, trimeric, tetrameric and even pentameric species were formed in the aged solution of OX in milli-Q water. The paucity of such multimeric species in the cell culture media, may indicate that complexation with constituents of the media had served to hinder the polymerisation reactions. It is also possible that the background noise in the spectra might have served to mask their presence. Finally, the presence of dimeric species was also reported in the aged solution of cisplatin [28]. 


\section{Proteomics}

Proteomics involving 2-D gel electrophoresis and mass spectrometry were employed to identify key proteins associated with drug resistance in A2780 ${ }^{\text {cisR }}$ ovarian cancer cell line. It was based on the idea that proteins associated with drug resistance would undergo marked changes in expression in the resistant A2780 ${ }^{\text {cisR }}$ cell line as compared to that in the parent A2780 cell line. It was also thought that the proteins in question might be restored back to normalcy after treatment with drugs in two aliquots that caused enhanced cell kill (although the involvement of multiple pathways both in apoptosis and cell survival may mean not all of the proteins need to be concurrently targeted to bring about the cell death). However, the difficulty in the extraction of hydrophobic proteins including transmembrane proteins means that the identification of proteins such as CTR1 and other platinum influx transporters may remain elusive. Furthermore, proteomic results provide only a static picture at a selected time point (or points) whereas the cells being dynamic in nature would undergo continual changes. Other drawbacks of proteomics include difficulty in extraction of proteins that are low in abundance and inability to provide a complete picture at the levels of organs and organisms [29]. Notwithstanding these limitations, in this study 390 proteins were identified of which 72 underwent significant changes in expression in the resistant $\mathrm{A} 2780^{\mathrm{cisR}}$ cells compared to the levels found in the parent A2780 cells. Administration of CS in two aliquots with a time gap restored the expressions of at least 22 proteins to levels comparable to those found in the parent cell line, of which 12 were down-regulated and 10 up-regulated prior to drug treatment. A summary of the proteins, their possible functions, and associations with neoplasia were given in Table 4 .

One of the proteins undergoing differential expression is mitochondrial cytochrome $\mathrm{c}$ oxidase subunit $5 \mathrm{~A}$ (COX5A) which is one of the 13 subunits that make up cytochrome c oxidase (COX), the terminal enzyme of the mitochondrial electron transport chain. It was down-regulated in untreated $\mathrm{A} 2780^{\text {cisR }}$ cell line as compared to the parent A2780 cell line, over-restored due to treatment with aged solution of CS administered in two aliquots with $2 \mathrm{~h}$ time gap but only partially-restored when the same treatment was given with fresh solution. Although the three largest subunits COX1, COX2 and COX3 form the catalytic core of cytochrome oxidase, COX5A coupled to COX4 is essential for the assembly of the entire unit [30] so that a decrease in the expression of COX5A may be an indicator of under performance of the entire enzyme. COX5A was found to be down-regulated in other cancers such as nasopharyngeal and gastric carcinomas [31, 32]. Thus, the up-regulation of COX5A in A2780 ${ }^{\text {cisR }}$ cells following treatment with solutions of CS administered in two aliquots with a time gap can be a factor responsible for the pronounced cell kill. Cofilin-2 (COF-2) was also down-regulated in A2780 ${ }^{\text {cisR }}$ cell line as compared to the parent A2780 cell line. Administration of fresh solution of CS in two aliquots with a $2 \mathrm{~h}$ time gap caused its full restoration whereas that with the aged solution led to over-restoration. The results indicate that COF-2, which is the major component of intranuclear and cytoplasmic actin rods that plays a critical role in the regulation of actin filament dynamics in eukaryotes [33], may be associated with platinum resistance in ovarian cancer and that the employed treatments have been able to overcome the mechanism of resistance applying to the protein. Another protein found to be downregulated in $\mathrm{A} 2780^{\mathrm{cisR}}$ as compared to that in A2780 cell line was $14-3-3 \gamma$. Present abundantly in the cytoplasm, 14-3-3 proteins participate in a wide variety of activities including DNA repair, apoptosis, the onset of cell differentiation and senescence, and the coordination of cell adhesion, motility, intracellular signalling and cell cycle control [34]. Administration of CS in two aliquots with $2 \mathrm{~h}$ time gap caused its partial restoration when fresh solutions were used but led to over-restoration with aged solutions.

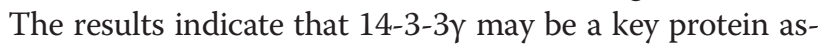
sociated with platinum resistance in ovarian cancer. Another protein of interest is MARE1 that belongs to the microtubule-associated protein $\mathrm{RP} / \mathrm{EB}$ family. It is a prototypic member of microtubule plus-end tracking proteins (+TIPs) that control microtubule dynamics and are associated with different cellular structures. MARE1 was down-regulated in A2780 ${ }^{\text {cisR }}$ ovarian cancer cell line as compared to A2780 cell line. The administration of CS in two aliquots with $2 \mathrm{~h}$ time gap led to its full restoration. Although down-regulation of MARE1 inhibits the formation of stable microtubule, the role of MARE1 in inducing chromosomal instability remains unclear [35]. The next identified protein was Annexin A1 that belongs to the annexin family of proteins that have been implicated in many molecular and cellular processes, including modulation of phospholipase A2 and kinase activities in signal transduction, maintenance of cytoskeleton and extracellular matrix integrity, tissue growth and differentiation, inflammation, and blood coagulation [36-38]. ANXA1 was found to be down-regulated in the CS-resistant A2780 cell line as compared to the parent A2780 cell line. The administration of CS in two aliquots with $2 \mathrm{~h}$ time gap fully restored ANXA1. The results indicate that ANXA1 may be playing an important role in drug resistance in ovarian cancer and that the administered combinations have been able to overcome associated mechanism of resistance. Another protein found to be down-regulated in the CS-resistant A2780 ${ }^{\text {cisR }}$ cell line, was nucleophosmin (NPM), also known as nucleolar phosphoprotein B23. The administration of $\mathrm{CS}$ in two aliquots caused its full 
restoration when fresh solutions were used but caused its over-restoration with the aged solution. The overexpression of the protein in $\mathrm{A} 2780^{\text {cisR }}$ cells due to treatment with the aged solution can be a reason why a greater cell kill was produced from the aged solution than fresh counterpart. A number of studies suggest that NPM is involved in cancer pathogenesis. In mice, inactivation of NPM in the germ line leads to a host of developmental defects that cause embryonic lethality at mid-gestation. Haploid-insufficiency of NPM leads to unrestricted centrosome duplication and genomic instability with mice developing myelodysplasia with an acceleration of oncogenesis [39]. Moreover, disruption of the NPM gene by translocation is frequently found in human hematopoietic malignancies [40]. The fact that NPM contributes to oncogenesis by activating the oncogenic potential of the fused protein partner, suggests that the down-regulation of NPM may also indicate the under-regulation of the tumour suppressors p53, Rb and ARF [41, 42]. Alphaenolase (ENOA) was also down-regulated in A2780 ${ }^{\text {cisR }}$ cell line as compared to the parent A2780 cell line. The protein acts as a transcriptional repressor and possibly functions as a tumour suppressor. Partial restoration occurred when A2780 ${ }^{\text {cisR }}$ cells were treated with fresh solutions of CS administered in two aliquots with $2 \mathrm{~h}$ time gap whereas the same with aged solutions caused its full restoration. The results indicate that the treatments in two aliquots using aged solutions of CS were able to overcome mechanism of resistance associated with ENOA. Another protein found to be down-regulated in CS-resistant A2780 ${ }^{\text {cisR }}$ cell line as compared to its CS sensitive counterpart was PDIA3. Partial and over-restoration of PDIA3 occurred when cells were treated respectively with fresh and aged solutions of CS administered in two aliquots. Although the expression of PDIA was found to be upregulated in some cancers such as breast, it was found to be down-regulated in other cancers such as gastric and prostate cancers [43-46]. Besides its role as a chaperone, it was suggested that PDIA3 might be functioning as a pro-apoptotic protein in prostate cancer; a decrease of caspase activity was related to due to down-regulation of PDIA3 in prostate cancer cell lines [46]. Down-regulation of PDIA3 might be playing a role in the late onset of prostate cancer progression. Down-regulation of PDIA3 also correlated with increased tumour invasion and advanced stage of gastric cancer. Hence PDIA3 has been proposed to be a negative prognostic marker [45]. In addition to its role in the ER stress pathway, PDIA3 has also gained attention due to its association with the major histocompatibility complex (MHC) class I pathway. In PDIA3 deficient mice, MHC I is impaired and negatively influences presentation of antigenic peptides helping tumours to escape from immune surveillance by cytotoxic $\mathrm{T}$ cells [47]. Although PDIA3 was found to be over-expressed in YDOV-
139 ovarian cancer cell line [48], in this study, CSresistant ovarian cancer cell line showed decreased levels of the protein compared to the parent cell line suggesting its involvement in resistance to cisplatin. As PDIA3 is reported to be up-regulated by hypoxia [49], low levels of PDIA3 found in A2780 ${ }^{\text {cisR }}$ cells indicate that the cells may not be under hypoxic stress.

Calumenin (CALU) was also up-regulated in the resistant $\mathrm{A} 2780^{\mathrm{cisR}}$ as compared to that in A2780 cell line. It is a ubiquitous calcium-binding protein localized in the endoplasmic reticulum and involved in such functions as protein folding and sorting [50]. Although the exact role of CALU is yet to be elucidated, the functions of the calcium-binding family are well understood. They have been associated with resistance to chemotherapeutic drugs [51, 52]. In this study, administration of fresh solution of CS in two aliquots with a $2 \mathrm{~h}$ time gap caused its over-restoration whereas that with aged solution of CS led to its partial-restoration. The results indicate that CALU may be associated with drug resistance and that the employed drug combinations have been able to overcome the associated mechanism. Another protein that was up-regulated in the $\mathrm{A} 2780^{\mathrm{cisR}}$ as compared to the parent A2780 cell line was the $40 \mathrm{~S}$ ribosomal protein SA (RSSA). The administration of CS in two aliquots using fresh solution fully restored its expression. The elevated expression of RSSA in the resistant A2780 ${ }^{\text {cisR }}$ cell line and its restoration back to normalcy due to synergistic treatments give support to the idea that the receptor is associated with metastasis and drug resistance. Laminin has been implicated in a wide variety of biological processes including cell adhesion, differentiation, migration, signalling, neurite outgrowth and metastasis. The protein also serves as a major adhesion substrate for invasive cancer cells. Indeed, there is a direct correlation between the ability of malignant cells to attach to laminin and their metastatic potential [53]. Thus, over-expression of RSSA was observed in many cancers indicating its potential role in tumour progression. Highly metastatic cancer cells are found to express at their surface significantly more laminin receptors than do their much less metastatic or benign counterparts [54]. Breast, cervical, colorectal and gastric carcinomas are found to express high levels of RSSA [54, 55]. Overexpression of this receptor is not restricted to epithelial tumours. For example, melanomas and lymphomas also display increased expression of the receptor [56, 57]. Next protein that was up-regulated in $\mathrm{A} 2780^{\text {cisR }}$ as compared to A2780 cell line was ACTB that is a member of the actin family. Actins are essential for a large range of cell functions including cell division, migration, junction formation, chromatin remodelling, transcriptional regulation, vesicle trafficking, and cell shape regulation [58]. Administration of CS in two aliquots using fresh 
solution caused its full restoration in $\mathrm{A} 2780^{\mathrm{cisR}}$ cell line but partial restoration when aged solutions were used. The results indicate the employed treatments were able to overcome the associated mechanism of resistance. Three HNRNP proteins identified in this study were HNRPC, HNRPF and HNRPK. HNRPF was downregulated whereas HNRPC and HNRPK were upregulated in the $\mathrm{A} 2780^{\mathrm{cisR}}$ cell line compared to the parent A2780 cell line. Although the proteins were differentially expressed in the resistant cell line, there does not appear to be a direct relationship between HNRNPs and cellular resistance to platinum drugs. ATPA and ATPB were up-regulated in the CS-resistant $A 2780^{\text {cisR }}$ cell line as compared to the parent A2780 cell line. Administration of both fresh and aged solutions of CS in two aliquots with $2 \mathrm{~h}$ time gap caused over-restoration of ATPB. ATP synthase has been implicated in angiogenesis, cellular immunity, cholesterol uptake and cellular $\mathrm{pH}$ regulation [59]. A novel approach by Juan et al. targeted the deregulation and over-expression of ATP synthase in breast cancer using an ATP synthase inhibitor [60]. It may be noted that the spot corresponding to ATPA was positioned in a cluster of spots that were closely placed and were of poor quality after treatment so that some uncertainty remained about ATPA. Further experiments would be needed to ascertain changes in expression of ATPA. However, ATP synthase appears to be associated with drug resistance and that the employed treatments were able to completely inhibit the expression of ATPB. The protein coded as T-complex protein 1 subunit theta (TCPQ/CCT $\theta)$ was down-regulated in $\mathrm{A} 2780^{\mathrm{cisR}}$ as compared to the level found in parent A2780 cell line. Although evidence is emerging about the diverse roles played by the complex, relatively little is known about the functional divergence of the individual subunits, and how this may relate their role in tumour development and progression. Treatment with solutions of CS given in two aliquots with $2 \mathrm{~h}$ time gap caused its over-restoration with fresh solution and partial restoration with aged solution. Another protein glucosidase 2 subunit beta coded as GLU2B was up-regulated in the $\mathrm{A} 2780^{\mathrm{cisR}}$ cell line as compared to the A2780 cell line. Though the exact function of GLU2B in cell differentiation is yet to be determined, it may be influencing glycosylation process of newly synthesized proteins and may act as a regulator of distinct developmental processes [61]. It was reported by Otto Warburg about 70 years ago that tumour cells exhibited an altered metabolism, characterized by increased glucose uptake and elevated glycolysis [62]. Indeed, an increase in the rate of glycolysis is one of the metabolic alterations found in most cancer cells $[63,64]$. GLU2B was over-restored in A2780 ${ }^{\text {cisR }}$ cell line due to the administration of fresh solution of CS given in two aliquots with a time gap but the same with aged solutions had no effect on the expression of GLU2B. The results suggest that GLU2 may be associated with drug resistance in ovarian cancer although the enhanced cell kill associated with aged solutions cannot be related to the protein. Calreticulin (CALR) that is a multifunctional protein that acts as a major calcium-binding protein in the lumen of the endoplasmic reticulum [65], was up-regulated in the CSresistant $\mathrm{A} 2780^{\mathrm{cisR}}$ cell line as compared to the parent A2780 cell. It is involved in a wide variety of cellular processes including modulation of calcium signals, storage and buffering of calcium, regulation of steroiddependent gene expression via direct interaction with steroid receptors, cell adhesion via direct binding to integrin $\alpha$, a chaperone in protein folding, autoimmune response and long-term neuromodulations [66]. Downregulation of CALR by antisense was found to increase sensitivity of neuroblastoma $\times$ glioma NG-108-15 cells to cytotoxic calcium overload [67]. In contrast, upregulation of CALR has been shown to protect HeLa cells from apoptosis [66]. Nakajo et al. reported that the expression of CALR markedly decreased before the apoptosis event in human leukemia HL-60 cells [68]. Furthermore, increased expression of CALR was a poor prognostic factor in diverse tumours including neuroblastoma, bladder cancer, and non-Hodgkin's lymphoma [69]. Interestingly, CALR is thought to function as a pro-phagocytic signal highly expressed on the surface of several human cancers, but minimally expressed on normal cell counterparts line [69]. The protein was fullyrestored due to treatment with fresh solutions of CS given in two aliquots with a time gap whereas treatment with the aged solutions caused its over-restoration. The results can be seen to indicate that CALR may be associated with platinum resistance in ovarian cancer. Next protein that was found to be up-regulated in CSresistant $\mathrm{A} 2780^{\mathrm{cisR}}$ cell line as compared to the parent A2780 cell line was vimentin (VIME). VIME is ubiquitously expressed in normal mesenchymal cells and known to maintain cellular integrity and provide resistance against stress. Increased expression of VIME has been reported in many epithelial cancers including melanoma, prostate, gastric, oesophageal, hepatocellular, pancreatic and breast carcinomas [70-73]. The overexpression of VIME in cancer is extensively reported to correlate with increased tumour growth, invasion, metastasis and poor prognosis [74]. In contrast, downregulation of VIME inhibits carcinoma cell migration and adhesion [75]. VIME has gained much importance as a marker of epithelial-mesenchymal transition (EMT); a cellular reprogramming process in which the epithelial cells acquire a mesenchymal phenotype that renders the cells to significantly alter their shape and show increased motility [76]. It was over-restored due to treatment with 
fresh solutions of CS administered in two aliquots with a time gap whereas the same with the aged solutions had no significant effect on its expression. The results suggest that VIME may be associated with platinum resistance and that the increase in its expression may be associated with poor prognosis in platinum refractory ovarian cancer. A number of heat shock proteins (HSP) were also found to be differentially expressed in A2780 $0^{\text {cisR }}$ cell line as compared to A2780 cell line. The first was chaperonin $60 \mathrm{kDa}(\mathrm{CH} 60)$ also known as HSP60. It was up-regulated in $\mathrm{A} 2780^{\text {cisR }}$ cell line as compared to $\mathrm{A} 2780$ cell line. The protein was restored back when the cells were treated with solutions of CS administered in two aliquots - over-restored in the case of fresh solution and partially restored in the case of aged solution. The results indicate that the over-expression of HSP60 may provide the cells with survival advantage by making them more tolerant against drugs and that the employed drug treatments were able to overcome the associated mechanism of resistance. Three HSPs belonging to the HSP-70 family (HSP-70s) namely HSP7C, HSP74 and GRP75 were also identified in the study. HSP74 was down regulated in A2780 ${ }^{\text {cisR }}$ cell line as compared to the parent A2780 cell line. It was over-restored due to treatment with fresh solution of CS administered in two aliquots and partially restored when the same was given using aged solution. HSP7C did not show any change in expression in A2780 ${ }^{\text {cisR }}$ cell line as compared to A2780 cell line. The results of the study show that whereas HSP74 may be associated with CS resistance in the tested ovarian cancer cell lines, HSP7C may not be so. GRP75 was also slightly down-regulated in A2780 ${ }^{\text {cisR }}$ as compared to A2780 cell line. It was partially and fully-restored when the cells were treated with fresh and aged solutions of CS administered in two aliquots respectively. The expression pattern of GRP75 suggests that the protein may not be a major player in CS resistance.

In summary belongingness of the 22 identified proteins to various functional groupings such as invasion and metastasis, cell cycle regulation and proliferation, metabolic and biosynthesis processes, stress-related proteins and chaperones, mRNA processing, cellular organization/cytoskeleton, cellular communication and signal transduction highlights that platinum resistance is multifactorial in nature in which many proteins with diverse functions may be playing key roles; inevitably the loss of control of functions can endow tumour cells with the ability to escape programmed cell death and proliferate without control. The results also indicate that multiple strategies can be gainfully employed to overcome the resistance.

\section{Putting into context}

With the idea that the effect of administration of platinum drugs in two aliquots with a time gap may induce changes in multiple parameters, in addition to changes in the combined drug action, cellular accumulation of platinum, level of platinum-DNA binding, cellular glutathione level and changes in protein expression were also determined. Whereas the combined drug action was quantified for all aliquoted administrations, the cellular accumulation of platinum, level of platinum - DNA, cellular glutathione levels and proteomic studies were carried out for a subset of the experiments. It was thought that a careful consideration of the results for the subset might lead to more meaningful conclusions. Table 5 provides a summary of all the results for the subset.

Table 5 Summary of results following treatment of $A 2780^{\text {cisR }}$ cell line with CS administered in two aliquots with $2 \mathrm{~h}$ time gap

\begin{tabular}{|c|c|c|c|c|c|c|c|c|c|c|}
\hline & \multicolumn{2}{|c|}{ Cytotoxic effect } & \multicolumn{2}{|c|}{ Cellular accumulation } & \multicolumn{2}{|c|}{ DNAbinding } & \multicolumn{4}{|c|}{ Proteomics $^{a}$} \\
\hline & Fresh & Aged & Fresh & Aged & Fresh & Aged & Fresh & & Aged & \\
\hline \multicolumn{11}{|c|}{$C S+C S$} \\
\hline $2 \mathrm{~h}$ & Antagonistic & Synergistic & Unchanged & Increased & Increased & Greater increase & $\begin{array}{l}\text { COF2 } \\
\text { MARE1 } \\
\text { NPM } \\
\text { ANXA1 } \\
\text { RSSA } \\
\text { ACTB } \\
\text { CALU } \\
\text { HNRPF } \\
\text { ATPA } \\
\text { HNRPK } \\
\text { CH60 } \\
\text { TCPQ } \\
\text { GLU2B } \\
\text { HSP74 } \\
\text { HNRPC } \\
\text { CALR } \\
\text { VIME }\end{array}$ & $\begin{array}{l}(\mathrm{D}, \mathrm{R}), \\
(\mathrm{D}, \mathrm{R}), \\
(\mathrm{D}, \mathrm{R}), \\
(\mathrm{D}, \mathrm{R}), \\
(\mathrm{U}, \mathrm{R}), \\
(\mathrm{U}, \mathrm{R}), \\
(\mathrm{U}, \mathrm{OR}), \\
(\mathrm{D}, \mathrm{R}), \\
(\mathrm{U}, \mathrm{OR}), \\
(\mathrm{U}, \mathrm{OR}), \\
(\mathrm{U}, \mathrm{OR}), \\
(\mathrm{D}, \mathrm{OR}), \\
(\mathrm{U}, \mathrm{OR}), \\
(\mathrm{D}, \mathrm{OR}), \\
(\mathrm{U}, \mathrm{R}), \\
(\mathrm{U}, \mathrm{R}), \\
(\mathrm{U}, \mathrm{OR}) .\end{array}$ & $\begin{array}{l}\text { COX5A } \\
\text { COF2 } \\
1433 \gamma \\
\text { MARE1 } \\
\text { NPM } \\
\text { ANXA1 } \\
\text { HNRPF } \\
\text { ENOA } \\
\text { ATPA } \\
\text { PDIA3 } \\
\text { TCPQ } \\
\text { GRP75 } \\
\text { HNRPC } \\
\text { CALR }\end{array}$ & $\begin{array}{l}(\mathrm{D}, \mathrm{OR}) \\
(\mathrm{D}, \mathrm{OR}) \\
(\mathrm{D}, \mathrm{OR}) \\
(\mathrm{D}, \mathrm{OR}) \\
(\mathrm{D}, \mathrm{OR}) \\
(\mathrm{D}, \mathrm{OR}) \\
(\mathrm{D}, \mathrm{OR}) \\
(\mathrm{D}, \mathrm{R}), \\
(\mathrm{U}, \mathrm{OR}) \\
(\mathrm{D}, \mathrm{R}), \\
(\mathrm{D}, \mathrm{R}), \\
(\mathrm{D}, \mathrm{R}), \\
(\mathrm{U}, \mathrm{R}), \\
(\mathrm{U}, \mathrm{OR})\end{array}$ \\
\hline
\end{tabular}

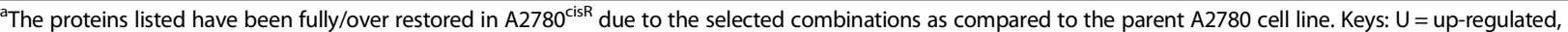
$\mathrm{D}=$ down-regulated, $\mathrm{OR}=$ over-restored, $\mathrm{R}=$ fully-restored 
Although treatment with fresh solution was found to be less synergistic to antagonistic (whereas that with aged solution was more synergistic), both the cellular accumulation of platinum and the level of platinum DNA binding were elevated due to treatment of A2780 ${ }^{\text {cisR }}$ cells with the fresh solution of CS in two aliquots. The failure of the increased cellular accumulation of platinum and more importantly that of the increased level of platinum-DNA binding to translate into enhanced cell death highlights the fact that although platinum - DNA binding can be a necessary step towards programmed cell death, it is not sufficient as apoptosis is brought about by downstream processes in the cell cycle in which many proteins may be playing key roles. The presence of crosstalk between pro-apoptotic and anti-apoptotic pathways can also be seen to complicate the situation.

For the antagonistic administration of CS in two aliquots using fresh solution, the following proteins: ACTB, CALU, CH60, GLU2B, HSP74 and VIME in treated $\mathrm{A} 2780^{\text {cisR }}$ cells were fully or over restored to the levels found in the parent A2780 cell line. In contrast, for the administration of CS in two aliquots using aged solution which was synergistic in action, the following proteins: COX5A, 1433y, ENOA, ATPA, PDIA3 and GRP75 were fully or over restored in treated $\mathrm{A} 2780^{\text {cisR }}$ cells as compared to the levels found in untreated A2780 cells. This is illustrated in the Venn diagram below (Fig. 9) where the proteins listed in red namely COX5A, 1433y, ENOA, PDIA3 and GRP75 are considered to be characteristic of incubation of cells with aged solution CS in two aliquots with $2 \mathrm{~h}$ time gap (Fig. 10).

COX5A, 1433G, ENOA, PDIA3 and GRP75 that are characteristic of synergistic administration of aged solution CS in two aliquots with $2 \mathrm{~h}$ time gap were initially down-regulated in the resistant cell line but up-

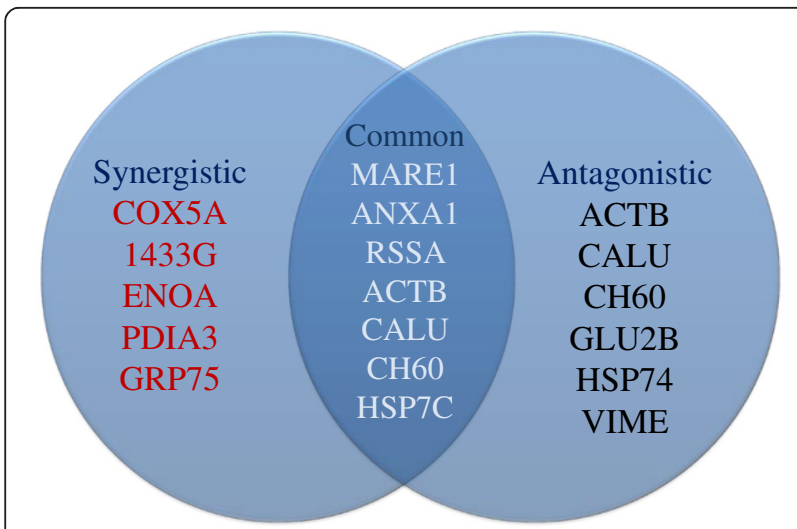

Fig. 10 Venn diagram listing the proteins expressed in $\mathrm{A} 2780^{\text {cisR }}$ cells that were restored or over restored compared to the levels found in A2780 cells after treatment of cells with aged (synergistic) and fresh (antagonistic) solutions of CS in two aliquots with $2 \mathrm{~h}$ time gap regulated following the drug treatment indicating that these proteins may be playing a pro-apoptotic role so that their down-regulation served to dampen cell death. In contrast, the proteins: MARE1, ANXA1, RSSA, ACTB, CALU, CH60 and HSP7C that were restored due to treatment with both synergistic and antagonistic combinations, may not be so critically associated with synergistic drug action in spite of them being a hallmark of cancer cell biology and platinum drug resistance. The results of the present study can be seen to confirm that synergistic administration of drugs may provide a means of overcoming drug resistance due to the reestablishment of cellular control functions.

\section{Conclusion}

The results of the present study show that when platinum drugs are administered in two aliquots with a time gap, a greater cell kill is produced from treatment with aged solutions than that with fresh ones. A smaller decrease in cellular GSH level in both A2780 and A2780 ${ }^{\text {cisR }}$ cells after treatment with CS and CB given in two aliquots than as a bolus, indicates that the increased activity resulting from administration in two aliquots cannot be due to changes in GSH. The increased activity on ageing is believed to be related to speciation of the drug in solution. Proteomic studies have identified 72 proteins that were differentially expressed in A2780 and A2780 ${ }^{\text {cisR }}$ cell lines, 22 of them were restored back to the levels found in the parent cell line as a result of synergistic treatments, indicating their relevance in synergistic drug action. Among them COX5A, 1433G, ENOA, PDIA3 and GRP75 that were down-regulated in the resistant A2780 ${ }^{\text {cisR }}$ cell line as compared to that in parent A2780 cell line but up-regulated after synergistic treatments, are considered to play a more critical role in bringing about apoptotic cell death. In contrast, MARE1, ANXA1, RSSA, ACTB, CALU, CH60 and HSP7C which were restored due to treatment with both synergistic and antagonistic combinations, may not be so critically involved in apoptosis or escape from it, in spite of them being a hallmark of cancer cell biology and platinum drug resistance. Finally, it should be stated that a major limitation of the study is that it gives a static picture. However, cells are dynamic in which changes (especially for proteins) are constant.

\footnotetext{
Acknowledgements

Part of the proteomic work was undertaken at APAF the Infrastructure provided by the Australian Government through the National Collaborative Research Infrastructure Strategy (NCRIS).

Zaynab Al-Eisawi is grateful to the Discipline of Biomedical Science, Sydney Medical School, The University of Sydney for the Discipline of Biomedical Science PhD Research Scholarship.
}

\section{Funding}

This research is partly supported by Biomedical Science Research Initiative Grant and Cancer Research Donation Fund. 


\section{Availability of data and materials}

The datasets supporting the conclusions of this article are included within the article.

\section{Authors' contributions}

ZA developed the methodology, acquired and interpreted data, and drafted the manuscript. PB, CC and JQY aided in study design. FH designed the study, developed the methodology, interpreted data, edited the manuscript, and oversaw the study. NP contributed to mass spectral analysis and read the manuscript. MM contributed to proteomics and read the manuscript. Finally, all authors have read and approved final the manuscript.

\section{Competing interests}

The authors declare that they have no competing interests.

\section{Consent for publication}

Not applicable.

\section{Ethics approval and consent to participate}

Not applicable.

\section{Author details}

${ }^{1}$ Discipline of Biomedical Science, Sydney Medical School, University of Sydney, Sydney, NSW 2141, Australia. ${ }^{2}$ Sydney Cancer Centre, Concord Hospital, Sydney, NSW 2139, Australia. ${ }^{3}$ Department of Pathology, Concord Hospital, Sydney, NSW 2139, Australia. ${ }^{4}$ Mass Spectrometry Unit, School of Chemistry, University of Sydney, Sydney, NSW 2006, Australia. ${ }^{5}$ Australian Proteome Analysis Facility, Macquarie University, Sydney, NSW 2109, Australia. ${ }^{6}$ Department of Medical Laboratory Sciences, Faculty of Allied Health Science, Hashemite University, Zarqa, Hashemite Kingdom of Jordan. ${ }^{7}$ Discipline of Biomedical Science, School of Medical Sciences, Sydney Medical School, The University of Sydney, Cumberland Campus C42, 75 East Street, Lidcombe, NSW 1825, Australia.

\section{Received: 8 August 2014 Accepted: 28 June 2016}

\section{Published online: 26 August 2016}

\section{References}

1. Wang D, Lippard SJ. Cellular processing of platinum anticancer drugs. Nat Rev Drug Discov. 2005;4:307-20.

2. Siddik ZH. Cisplatin: mode of cytotoxic action and molecular basis of resistance. Oncogene. 2003;22:7265-79.

3. Muggia FM, Los G. Platinum resistance: laboratory findings and clinical implications. Stem Cells. 1993;11:182-93.

4. Wu YJ, Muldoon LL, Neuwelt EA. The Chemoprotective Agent NAcetylcysteine Blocks Cisplatin-Induced Apoptosis through Caspase Signaling Pathway. J Pharmacol Exp Ther. 2005;312:424-31.

5. Al-Eisawi Z, Beale P, Chan C, Yu JQ, Huq F. Modulation of Cisplatin Cytotoxicity due to its Combination with Bortezomib and the Nature of its Administration. Anticancer Res. 2011;31:2757-62.

6. Dhara SC. Rapid method for the synthesis of cis[Pt( $\left.\left(\mathrm{NH}_{3}\right)_{2} \mathrm{Cl}_{2}\right]$. Indian J Chem. 1970;8:193-4.

7. Mosmann T. Rapid colorimetric assay for cellular growth and survival: application to proliferation and cytotoxicity assays. J Immunol Methods. 1983;65:55-63.

8. Chou TC. Drug Combination Studies and Their Synergy Quantification Using the Chou-Talalay Method. Cancer Res. 2010;70:440-6.

9. Chou TC. Theoretical Basis, Experimental Design, and Computerized Simulation of Synergism and Antagonism in Drug Combination Studies. Pharmacol Rev. 2006;58:621-81.

10. Chou TC, Talalay P. Quantitative analysis of dose-effect relationships: the combined effects of multiple drugs or enzyme inhibitors. Adv Enzyme Regul. 1984;22:27-55.

11. Al-Eisawi Z, Beale P, Chan C, Yu J, Huq F. Carboplatin and oxaliplatin in sequenced combination with bortezomib in ovarian tumour models. J Ovarian Res. 2013;6:78.

12. Bowtell DDL. Rapid isolation of eukaryotic DNA. Anal Biochem. 1987:162: 463-5.

13. Balendiran GK, Dabur R, Fraser D. The role of glutathione in cancer. Cell Biochem Funct. 2004;22:343-52.
14. Godwin AK, Meister A, O'Dwyer PJ, Huang CS, Hamilton TC, Anderson ME. High resistance to cisplatin in human ovarian cancer cell lines is associated with marked increase of glutathione synthesis. Proc Natl Acad Sci. 1992;89: 3070-4.

15. Rabik CA, Dolan ME. Molecular mechanisms of resistance and toxicity associated with platinating agents. Cancer Treat Rev. 2007;33:9-23.

16. Sharma S, Gong P, Temple B, Bhattacharyya D, Dokholyan NV, Chaney SG. Molecular Dynamic Simulations of Cisplatin- and Oxaliplatin-d(GG) ntrastand Cross-links Reveal Differences in their Conformational Dynamics. J Mol Biol. 2007;373:1123-40.

17. Wu Y, Bhattacharyya D, King CL, Baskerville-Abraham I, Huh SH, Boysen G, et al. Solution Structures of a DNA Dodecamer Duplex with and without a Cisplatin 1,2-d(GG) Intrastrand Cross-Link: Comparison with the Same DNA Duplex Containing an Oxaliplatin 1,2-d(GG) Intrastrand Cross-Link. Biochemistry (Mosc). 2007:46:6477-87.

18. Vogelstein B, Lane D, Levine AJ. Surfing the p53 network. Nature. 2000;408: $307-10$.

19. Yuan Z, Cao K, Lin C, Li L, Liu HY, Zhao XY, et al. The p53 upregulated modulator of apoptosis (PUMA) chemosensitizes intrinsically resistant ovarian cancer cells to cisplatin by lowering the threshold set by BCl-xL and Mcl-1. Mol Med. 2011;17:1262-74.

20. Kelland LR, Farrell NP. Platinum-Based Drugs in Cancer Therapy. 1st ed. New Jersey: Humana Press; 2000.

21. Yachnin JR, Wallin I, Lewensohn R, Sirzén F, Ehrsson H. The kinetics and cytotoxicity of cisplatin and its monohydrated complex. Cancer Lett. 1998: 132:175-80.

22. Zisowsky J, Koegel S, Leyers S, Devarakonda K, Kassack MU, Osmak M, et al. Relevance of drug uptake and efflux for cisplatin sensitivity of tumor cells. Biochem Pharmacol. 2007;73:298-307.

23. Zhang S, Lovejoy KS, Shima JE, Lagpacan LL, Shu Y, Lapuk A, et al. Organic Cation Transporters Are Determinants of Oxaliplatin Cytotoxicity. Cancer Res. 2006;66:8847-57.

24. Hagrman D, Goodisman J, Souid A-K. Kinetic Study on the Reactions of Platinum Drugs with Glutathione. J Pharmacol Exp Ther. 2004;308:658-66.

25. Michalke B. Platinum speciation used for elucidating activation or inhibition of Pt-containing anti-cancer drugs. J Trace Elem Med Biol. 2010;24:69-77.

26. Di Francesco AM, Ruggiero A, Riccardi R. Cellular and molecular aspects of drugs of the future: oxaliplatin. Cell Mol Life Sci. 2002;59:1914-27.

27. Townsend DM, Marto JA, Deng M, MacDonald TJ, Hanigan MH. High Pressure Liquid Chromatography and Mass Spectrometry Characterization of the Nephrotoxic Biotransformation Products of Cisplatin. Drug Metab Dispos. 2003;31:705-13.

28. Cui M, Mester Z. Electrospray ionization mass spectrometry coupled to liquid chromatography for detection of cisplatin and its hydrated complexes. Rapid Commun Mass Spectrom. 2003;17:1517-27.

29. Klein JB, Thongboonkerd V. Proteomics in Nephrology. Switzerland: Karger; 2004.

30. Fornuskova D, Stiburek L, Wenchich L, Vinsova K, Hansikova H, Zeman J. Novel insights into the assembly and function of human nuclear-encoded cytochrome c oxidase subunits 4, 5a, 6a, 7a and 7b. Biochem J. 2010;428: 363-74.

31. Nishigaki R, Osaki M, Hiratsuka M, Toda T, Murakami K, Jeang K-T, et al. Proteomic identification of differentially-expressed genes in human gastric carcinomas. Proteomics. 2005;5:3205-13.

32. Liu J, Zhan X, Li M, Li G, Zhang P, Xiao Z, et al. Mitochondrial proteomics of nasopharyngeal carcinoma metastasis. BMC Med Genomics. 2012;5:62.

33. Agrawal PB, Joshi M, Savic T, Chen Z, Beggs AH. Normal myofibrillar development followed by progressive sarcomeric disruption with actin accumulations in a mouse $\mathrm{Cfl} 2$ knockout demonstrates requirement of cofilin-2 for muscle maintenance. Hum Mol Genet. 2012;21.

34. Fu H, Subramanian RR, Masters SC. 14-3-3 Proteins: Structure, Function, and Regulation. Annu Rev Pharmacol Toxicol. 2000;40:617-47.

35. Wen Y, Eng CH, Schmoranzer J, Cabrera-Poch N, Morris EJS, Chen M, et al. EB1 and APC bind to mDia to stabilize microtubules downstream of Rho and promote cell migration. Nat Cell Biol. 2004;6:820-30.

36. Garcia Pedrero JM, Fernandez MP, Morgan RO, Herrero Zapatero A, Gonzalez MV, Suarez Nieto C, et al. Annexin A1 Down-Regulation in Head and Neck Cancer Is Associated with Epithelial Differentiation Status. Am J Pathol. 2004;164:73-9.

37. Mulla A, Christian HC, Solito E, Mendoza N, Morris JF, Buckingham JC Expression, subcellular localization and phosphorylation status of annexins 1 
and 5 in human pituitary adenomas and a growth hormone-secreting carcinoma. Clin Endocrinol (Oxf). 2004;60:107-19.

38. Fernandez MP, Morgan RO, Fernandez MR, Carcedo MT. The gene encoding human annexin $V$ has a TATA-less promoter with a high $\mathrm{G}+\mathrm{C}$ content. Gene. 1994;149:253-60.

39. Grisendi S, Bernardi R, Rossi M, Cheng K, Khandker L, Manova K, et al. Role of nucleophosmin in embryonic development and tumorigenesis. Nature. 2005:437:147-53.

40. Lim MJ, Wang XW. Nucleophosmin and human cancer. Cancer Detect Prev. 2006;30:481-90.

41. Bertwistle D, Sugimoto M, Sherr CJ. Physical and Functional Interactions of the Arf Tumor Suppressor Protein with Nucleophosmin/B23. Mol Cell Biol. 2004:24:985-96.

42. Kurki S, Peltonen K, Latonen L, Kiviharju TM, Ojala PM, Meek D, et al. Nucleolar protein NPM interacts with HDM2 and protects tumor suppressor protein p53 from HDM2-mediated degradation. Cancer Cell. 2004;5:465-75.

43. Updike MS, Sawdy JC, Wang L-S, Liu S, Huang Y-W, Ye W, et al. Primary cultured human breast epithelial cells up-regulate protein disulfide isomerase in response to zeranol. Anticancer Res. 2007;27:407-10.

44. Lee HH, Lim CA, Cheong YT, Singh M, Gam LH. Comparison of Protein Expression Profiles of Different Stages of Lymph Nodes Metastasis in Breast Cancer. Int J Biol Sci. 2012:8:353-62.

45. Leys CM, Nomura S, Lafleur BJ, Ferrone S, Kaminishi M, Montgomery E, et al. Expression and prognostic significance of prothymosin-a and ERp57 in human gastric cancer. Surgery. 2007;141:41-50.

46. Pressinotti N, Klocker H, Schafer G, Luu V-D, Ruschhaupt M, Kuner R, et al. Differential expression of apoptotic genes PDIA3 and MAP3K5 distinguishes between low- and high-risk prostate cancer. Mol Cancer. 2009;8:130.

47. Garbi N, Tanaka S, Momburg F, Hammerling GJ. Impaired assembly of the major histocompatibility complex class I peptide-loading complex in mice deficient in the oxidoreductase ERp57. Nat Immunol. 2006;7:93-102.

48. Chay D, Cho H, Lim BJ, Kang ES, Oh YJ, Choi SM, et al. ER-60 (PDIA3) is highly expressed in a newly established serous ovarian cancer cell line, YDOV-139. Int J Oncol. 2010;37:399-412.

49. Graven KK, Molvar C, Roncarati JS, Klahn BD, Lowrey S, Farber HW. Identification of protein disulfide isomerase as an endothelial hypoxic stress protein. Am J Physiol Lung Cell Mol Physiol. 2002;282:L996-L1003.

50. Yabe D, Taniwaki M, Nakamura T, Kanazawa N, Tashiro K, Honjo T. Human Calumenin Gene (CALU): CDNA Isolation and Chromosomal Mapping to 7q32. Genomics. 1998:49:331-3.

51. Takazawa K, Tsuchiya H, Yoshimichi U, Kanazawa Y, Sadao I, Tomita K. Expression analysis for the identification of genes involved in acquired resistance to cisplatin in osteosarcoma cells. Cancer Genomics Proteomics. 2006;3:373-82

52. Hegde R, Thimmaiah P, Yerigeri MC, Krishnegowda G, Thimmaiah KN, Houghton PJ. Anti-calmodulin acridone derivatives modulate vinblastine resistance in multidrug resistant (MDR) cancer cells. Eur J Med Chem. 2004; 39:161-77.

53. Ménard S, Castronovo V, Tagliabue E, Sobel ME. New insights into the metastasis-associated 67 kD laminin receptor. J Cell Biochem. 1997;67:155-65.

54. Cioce V, Castronovo V, Shmookler BM, Garbisa S, Grigioni WF, Liotta LA, et al. Increased Expression of the Laminin Receptor in Human Colon Cancer. J Natl Cancer Inst. 1991:83:29-36.

55. Castronovo V, Campo E, Brûle FA, Claysmith AP, Cioce V, Liu F-T, et al. Inverse Modulation of Steady-State Messenger RNA Levels of Two NonIntegrin Laminin-Binding Proteins in Human Colon Carcinoma. J Natl Cancer Inst. 1992;84:1161-9.

56. Carbone A, Gloghini A, Colombatti A, Castronovo V, Menard S. Expression of the monomeric 67-kd laminin-binding protein in human lymphomas as defined by MLUC5 monoclonal antibody and paraffin section immunohistochemistry. Hum Pathol. 1995;26:541-6.

57. Vacca A, Ribatti D, Roncali L, Lospalluti M, Serio G, Carrel S, et al. Melanocyte tumor progression is associated with changes in angiogenesis and expression of the 67-kilodalton laminin receptor. Cancer. 1993;72:455-61.

58. Perrin BJ, Ervasti JM. The actin gene family: function follows isoform Cytoskeleton. 2010;67:630-4.

59. Chi SL, Pizzo SV. Cell surface F1Fo ATP synthase: A new paradigm? Ann Med. 2006;38:429-38.

60. Juan HF, Chang HY, Huang TC, Hsu CH, Kuo WH, Chang KJ. Method of treating cancer using ATP synthase inhibitors. US patent no. 514456 National Taiwan University. 2010.
61. Hoffrogge R, Beyer S, Hübner R, Mikkat S, Mix E, Scharf C, et al. 2-DE profiling of GDNF overexpression-related proteome changes in differentiating ST14A rat progenitor cells. Proteomics. 2007;7:33-46.

62. Warburg $\mathrm{O}$. The Metabolism of Tumours: Investigations from the Kaiser Wilhelm Institute for Biology. Br J Surg. 1930;19:168.

63. Lee $\mathrm{HC}$, Yin $\mathrm{PH}$, Lin JC, Wu CC, Chen CY, Wu CW, et al. Mitochondrial Genome Instability and mtDNA Depletion in Human Cancers. Ann N Y Acad Sci. 2005;1042:109-22

64. Young C, Anderson S. Sugar and fat - that's where it's at: metabolic changes in tumors. Breast Cancer Res. 2008;10:202.

65. Michalak M, Milner RE, Burns K, Opas M. Calreticulin. Biochem J. 1992;285: 681-92.

66. Zhu N, Pewitt EB, Cai X, Cohn EB, Lang S, Chen R, et al. Calreticulin: An Intracellular $\mathrm{Ca}++-$ Binding Protein Abundantly Expressed and Regulated by Androgen in Prostatic Epithelial Cells. Endocrinology. 1998;139:4337-44.

67. Liu N, Fine RE, Simons E, Johnson RJ. Decreasing calreticulin expression lowers the $\mathrm{Ca}^{2+}$ response to bradykinin and increases sensitivity to ionomycin in NG-108-15 cells. J Biol Chem. 1994;269:28635-9.

68. Nakajo S, Okamoto M, Masuda Y, Sakai I, Ohsawa S, Nakaya K. Geranylgeraniol Causes a Decrease in Levels of Calreticulin and Tyrosine Phosphorylation of a 36-kDa Protein Prior to the Appearance of Apoptotic Features in HL-60 Cells. Biochem Biophys Res Commun. 1996;226:741-5.

69. Chao MP, Jaiswal S, Weissman-Tsukamoto R, Alizadeh AA, Gentles AJ, Volkmer J, et al. Calreticulin Is the Dominant Pro-Phagocytic Signal on Multiple Human Cancers and Is Counterbalanced by CD47. Sci Transl Med. 2010;2:63ra94

70. Wu M, Bai X, Xu G, Wei J, Zhu T, Zhang Y, et al. Proteome analysis of human androgen-independent prostate cancer cell lines: Variable metastatic potentials correlated with vimentin expression. Proteomics. 2007;7:1973-83.

71. Takemura K, Hirayama R, Hirokawa K, Inagaki M, Tsujimura K, Esaki Y, et al. Expression of Vimentin in Gastric Cancer: A Possible Indicator for Prognosis. Pathobiology. 1994;62:149-54.

72. Jin H, Morohashi S, Sato F, Kudo Y, Akasaka H, Tsutsumi S, et al. Vimentin expression of esophageal squamous cell carcinoma and its aggressive potential for lymph node metastasis. Biomed Res. 2010;31:105-12.

73. Gilles C, Polette M, Mestdagt M, Nawrocki-Raby B, Ruggeri P, Birembaut $P$, et al. Transactivation of Vimentin by $\beta$-Catenin in Human Breast Cancer Cells. Cancer Res. 2003:63:2658-64.

74. Satelli A, Li S. Vimentin in cancer and its potential as a molecular target for cancer therapy. Cell Mol Life Sci. 2011;68:3033-46.

75. Mcinroy L, Määttä A. Down-regulation of vimentin expression inhibits carcinoma cell migration and adhesion. Biochem Biophys Res Commun. 2007;360:109-14.

76. Thiery JP. Epithelial-mesenchymal transitions in tumour progression. Nat Rev Cancer. 2002:2:442-54.

77. Herrmann PC, Gillespie JW, Charboneau L, Bichsel VE, Paweletz CP, Calvert VS, et al. Mitochondrial proteome: Altered cytochrome c oxidase subunit levels in prostate cancer. Proteomics. 2003;3:1801-10.

78. De LC-HE, Perez-Plasencia C, Perez-Cardenas E, Gonzalez-Fierro A, TrejoBecerril C, Chavez-Blanco A, et al. Transcriptional changes induced by epigenetic therapy with hydralazine and magnesium valproate in cervical carcinoma. Oncol Rep. 2011;25:399-407.

79. Yusenko MV, Ruppert T, Kovacs G. Analysis of differentially expressed mitochondrial proteins in chromophobe renal cell carcinomas and renal oncocytomas by 2-D gel electrophoresis. Int J Biol Sci. 2010;6:213-24.

80. inventor. Identification of cytochrome oxidase COX4-2 as an early lung cancer diagnostic biomarker. Patent no. US patent classification. 2006.

81. Chen WL, Kuo KT, Chou TY, Chen CL, Wang CH, Wei YH, et al. The role of cytochrome c oxidase subunit Va in non-small cell lung carcinoma cells: association with migration, invasion and prediction of distant metastasis. BMC Cancer. 2012;12:273.

82. Telang S, Nelson K, Siow D, Yalcin A, Thornburg J, Imbert-Fernandez Y, et al Cytochrome c oxidase is activated by the oncoprotein Ras and is required for A549 lung adenocarcinoma growth. Mol Cancer. 2012;11:60.

83. Baris O, Savagner F, Nasser V, Loriod B, Granjeaud S, Guyetant S, et al. Transcriptional Profiling Reveals Coordinated Up-Regulation of Oxidative Metabolism Genes in Thyroid Oncocytic Tumors. J Clin Endocrinol Metab. 2004:89:994-1005

84. Wang Y, Kuramitsu Y, Ueno T, Suzuki N, Yoshino S, lizuka N, et al. Differential expression of up-regulated cofilin-1 and down-regulated cofilin-2 characteristic of pancreatic cancer tissues. Oncol Rep. 2011;26:1595-9. 
85. Zhu B, Fukada K, Zhu H, Kyprianou N. Prohibitin and cofilin are intracellular effectors of transforming growth factor $\beta$ signaling in human prostate cancer cells. Cancer Res. 2006;66:8640-7.

86. Song Y, Yang Z, Ke Z, Yao Y, Hu X, Sun Y, et al. Expression of 14-3-3Y in patients with breast cancer: Correlation with clinicopathological features and prognosis. Cancer Epidemiol. 2012;36:533-6.

87. Ladd JJ, Busald T, Johnson MM, Zhang Q, Pitteri SJ, Wang H, et al. Increased Plasma Levels of the APC-Interacting Protein MAPRE1, LRG1, and IGFBP2 Preceding a Diagnosis of Colorectal Cancer in Women. Cancer Prev Res (Phila Pa). 2012;5:655-64

88. Fujii K, Kondo T, Yokoo H, Yamada T, Iwatsuki K, Hirohashi S. Proteomic study of human hepatocellular carcinoma using two-dimensional difference gel electrophoresis with saturation cysteine dye. Proteomics. 2005;5:1411-22.

89. Kim K, Lee H-C, Park J-L, Kim M, Kim S-Y, Noh S-M, et al. Epigenetic regulation of microRNA-10b and targeting of oncogenic MAPRE1 in gastric cancer. Epigenetics. 2011;6:740-51.

90. Wang Y, Zhou X, Zhu H, Liu S, Zhou C, Zhang G, et al. Overexpression of EB1 in human esophageal squamous cell carcinoma (ESCC) may promote cellular growth by activating $\beta$-catenin/TCF pathway. Oncogene. 2005;24: $6637-45$.

91. Tsui KH, Cheng AJ, Chang PL, Pan TL, Yung BYM. Association of nucleophosmin/B23 mRNA expression with clinical outcome in patients with bladder carcinoma. Urology. 2004;64:839-44.

92. Skaar TC, Prasad SC, Sharareh S, Lippman ME, Brünner N, Clarke R. Twodimensional gel electrophoresis analyses identify nucleophosmin as an estrogen regulated protein associated with acquired estrogen-independence in human breast cancer cells. J Steroid Biochem Mol Biol. 1998;67:391-402.

93. Nozawa Y, Van Belzen N, Van Der Made ACJ, Dinjens WNM, Bosman FT Expression of Nucleophosmin/B23 in Normal and Neoplastic Colorectal Mucosa. J Pathol. 1996:178:48-52.

94. Tanaka M, Sasaki H, Kino I, Sugimura T, Terada M. Genes Preferentially Expressed in Embryo Stomach are Predominantly Expressed in Gastric Cancer. Cancer Res. 1992;52:3372-7.

95. Shields LB, Gerçel-Taylor C, Yashar CM, Wan TC, Katsanis WA, Spinnato JA, et al. Induction of immune responses to ovarian tumor antigens by multiparity. J Soc Gynecol Investig. 1997:4:298-304.

96. Subong ENP, Shue MJ, Epstein JI, Briggman JV, Chan PK, Partin AW. Monoclonal antibody to prostate cancer nuclear matrix protein (PRO:4-216) recognizes nucleophosmin/B23. Prostate. 1999;39:298-304.

97. Ahn SH, Sawada H, Ro JY, Nicolson GL. Differential expression of annexin I in human mammary ductal epithelial cells in normal and benign and malignant breast tissues. Clin Exp Metastasis. 1997;15:151-6.

98. Yu G, Wang J, Chen Y, Wang X, Pan J, Li Q, et al. Tissue microarray analysis reveals strong clinical evidence for a close association between loss of annexin A1 expression and nodal metastasis in gastric cancer. Clin Exp Metastasis. 2008;25:695-702.

99. Masaki T, Tokuda M, Ohnishi M, Watanabe S, Fujimura T, Miyamoto K, et al. Enhanced expression of the protein kinase substrate annexin in human hepatocellular carcinoma. Hepatology. 1996;24:72-81.

100. Paweletz CP, Ornstein DK, Roth MJ, Bichsel VE, Gillespie JW, Calvert VS, et al. Loss of annexin 1 correlates with early onset of tumorigenesis in esophageal and prostate carcinoma. Cancer Res. 2000;60:6293-7.

101. Xia SH, Hu LP, Hu H, Ying WT, Xu X, Cai Y, et al. Three isoforms of annexin I are preferentially expressed in normal esophageal epithelia but down-regulated in esophageal squamous cell carcinomas. Oncogene. 2002:21:6641-8.

102. Kang JS, Calvo BF, Maygarden SJ, Caskey LS, Mohler JL, Ornstein DK. Dysregulation of annexin I protein expression in high-grade prostatic intraepithelial neoplasia and prostate cancer. Clin Cancer Res. 2002;8:117-23.

103. Viacava P, Naccarato AG, Collecchi P, Ménard S, Castronovo V, Bevilacqua G. The Spectrum 67-kD Laminin Receptor Expression in Breast Carcinoma Progression. J Pathol. 1997;182:36-44.

104. Al-Saleh W, Delvenne P, Van Den Brule FA, Menard S, Boniver J, Castronovo V. Expression of the $67 \mathrm{kD}$ laminin receptor in human cervical preneoplastic and neoplastic squamous epithelial lesions: an immunohistochemical study. J Pathol. 1997;181:287-93.

105. Sanjuán X, Fernández PL, Miquel R, Muñoz J, Castronovo V, Ménard S, et al. Overexpression of the 67-kD Laminin Receptor Correlates with Tumour Progression in Human Colorectal Carcinoma. J Pathol. 1996;179:376-80.

106. Kumazoe M, Sugihara K, Tsukamoto S, Huang Y, Tsurudome Y, Suzuki T, et al. 67-kDa laminin receptor increases CGMP to induce cancer-selective apoptosis. J Clin Invest. 2013;123:787-99.
107. Nowak D, Skwarek-Maruszewska A, Zemanek-Zboch M, Malicka-Blaszkiewicz M. Beta-actin in human colon adenocarcinoma cell lines with different metastatic potential. Acta Biochim Pol. 2005;52:461-8.

108. Xu J, Zhang Z, Chen J, Liu F, Bai L. Overexpression of $\beta$-actin is closely associated with metastasis of gastric cancer. Hepatogastroenterology. 2013; 60:620-3.

109. Popow A, Nowak D, Malicka-Blaszkiewicz M. Actin cytoskeleton and betaactin expression in correlation with higher invasiveness of selected hepatoma Morris 5123 cells. J Physiol Pharmacol. 2006;57 Suppl 7:111-23.

110. Le PU, Nguyen TN, Drolet-Savoie P, Leclerc N, Nabi IR. Increased $\beta$-Actin Expression in an Invasive Moloney Sarcoma Virus-transformed MDCK Cell Variant Concentrates to the Tips of Multiple Pseudopodia. Cancer Res. 1998; 58:1631-5.

111. Volmer MW, Stühler K, Zapatka M, Schöneck A, Klein-Scory S, Schmiegel W, et al. Differential proteome analysis of conditioned media to detect Smad4 regulated secreted biomarkers in colon cancer. Proteomics. 2005;5:2587-601.

112. Kim B, Bang S, Lee S, Kim S, Jung Y, Lee C, et al. Expression Profiling and Subtype-Specific Expression of Stomach Cancer. Cancer Res. 2003;63:8248-55.

113. Zhang R, Tremblay T-L, McDermid A, Thibault P, Stanimirovic D. Identification of differentially expressed proteins in human glioblastoma cell lines and tumors. Glia. 2003;42:194-208.

114. Deprimo SE, Diehn M, Nelson JB, Reiter RE, Matese J, Fero M, et al. Transcriptional programs activated by exposure of human prostate cancer cells to androgen. Genome Biol. 2002;3:1.

115. Yang $Y-X$, Sun $X-F$, Cheng A-L, Zhang G-Y, Yi H, Sun $Y$, et al. Increased expression of HSP27 linked to vincristine resistance in human gastric cancer cell line. J Cancer Res Clin Oncol. 2009;135:181-9.

116. Pines A, Bivi N, Vascotto C, Romanello M, D'Ambrosio C, Scaloni A, et al. Nucleotide receptors stimulation by extracellular ATP controls Hsp90 expression through APE1/Ref-1 in thyroid cancer cells: A novel tumorigenic pathway. J Cell Physiol. 2006;209:44-55.

117. Tu SH, Chang CC, Chen CS, Tam KW, Wang YJ, Lee CH, et al. Increased expression of enolase $a$ in human breast cancer confers tamoxifen resistance in human breast cancer cells. Breast Cancer Res Treat. 2010;121:539-53.

118. Chang GC, Liu KJ, Hsieh CL, Hu TS, Charoenfuprasert S, Liu HK, et al. Identification of a-Enolase as an Autoantigen in Lung Cancer: Its Overexpression Is Associated with Clinical Outcomes. Clin Cancer Res. 2006:12:5746-54.

119. Cheng C, Long X, Li X, Xie M, Guo M. The expressions of alpha-enolase in the nasopharyngeal cancer tissue. J Clin otorhinolaryngol Head Neck Surg. 2011;25:554-6.

120. Duffy MJ. Predictive Markers in Breast and Other Cancers: A Review. Clin Chem. 2005;51:494-503.

121. Seth R, Keeley J, Abu-Ali G, Crook S, Jackson D, llyas M. The putative tumour modifier gene ATP5A1 is not mutated in human colorectal cancer cell lines but expression levels correlate with TP53 mutations and chromosomal instability. J Clin Pathol. 2009;62:598-603.

122. Kim NS, Hahn Y, Oh JH, Lee JY, Oh KJ, Kim JM, et al. Gene cataloging and expression profiling in human gastric cancer cells by expressed sequence tags. Genomics. 2004:83:1024-45

123. Hofmann WK, de Vos S, Elashoff D, Gschaidmeier H, Hoelzer D, Koeffler HP, et al. Relation between resistance of Philadelphia-chromosome-positive acute lymphoblastic leukaemia to the tyrosine kinase inhibitor STI571 and gene-expression profiles: a gene-expression study. Lancet. 2002;359:481-6.

124. Onda M, Emi M, Yoshida A, Miyamoto S, Akaishi J, Asaka S, et al. Comprehensive gene expression profiling of anaplastic thyroid cancers with cDNA microarray of 25344 genes. Endocr Relat Cancer. 2004;11:843-54.

125. Teramoto R, Minagawa H, Honda M, Miyazaki K, Tabuse Y, Kamijo K, et al. Protein expression profile characteristic to hepatocellular carcinoma revealed by 2D-DIGE with supervised learning. Biochim Biophys Acta Protein Proteomics. 2008;1784:764-72.

126. Chambery A, Farina A, Di Maro A, Rossi M, Abbondanza C, Moncharmont B, et al. Proteomic Analysis of MCF-7 Cell Lines Expressing the Zinc-Finger or the Proline-Rich Domain of Retinoblastoma-Interacting-Zinc-Finger Protein. J Proteome Res. 2006;5:1176-85.

127. Nagai MA, da Rós N, Neto MM, de Faria Junior SR, Brentani MM, Hirata R, et al. Gene expression profiles in breast tumors regarding the presence or absence of estrogen and progesterone receptors. Int J Cancer. 2004;111:892-9.

128. Kwong KY, Bloom GC, Yang I, Boulware D, Coppola D, Haseman J, et al. Synchronous global assessment of gene and protein expression in colorectal cancer progression. Genomics. 2005;86:142-58. 
129. Notari M, Neviani P, Santhanam R, Blaser BW, Chang J-S, Galietta A, et al. A MAPK/HNRPK pathway controls BCR/ABL oncogenic potential by regulating MYC mRNA translation. Blood. 2006;107:2507-16.

130. Perrotti D, Neviani P. From mRNA Metabolism to Cancer Therapy: Chronic Myelogenous Leukemia Shows the Way. Clin Cancer Res. 2007;13:1638-42.

131. Keenan J, Murphy L, Henry M, Meleady P, Clynes M. Proteomic analysis of multidrug-resistance mechanisms in adriamycin-resistant variants of DLKP, a squamous lung cancer cell line. Proteomics. 2009;9:1556-66.

132. Lohavanichbutr P, Houck J, Fan W, et al. Genomewide gene expression profiles of hpv-positive and hpv-negative oropharyngeal cancer: Potential implications for treatment choices. Arch Otolaryngol Head Neck Surg. 2009; 135:180-8.

133. Alldinger I, Dittert D, Peiper M, Fusco A, Chiappetta G, Staub E, et al. Gene expression analysis of pancreatic cell lines reveals genes overexpressed in pancreatic cancer. Pancreatology. 2005;5:370-9.

134. Cappello F, Di Stefano A, David S, Rappa F, Anzalone R, La Rocca G, et al. Hsp60 and Hsp10 down-regulation predicts bronchial epithelial carcinogenesis in smokers with chronic obstructive pulmonary disease. Cancer. 2006;107:2417-24.

135. Cappello F, David S, Rappa F, Bucchieri F, Marasa L, Bartolotta T, et al. The expression of HSP60 and HSP10 in large bowel carcinomas with lymph node metastase. BMC Cancer. 2005:5:139.

136. Thomas X, Campos L, Mounier C, Cornillon J, Flandrin P, Le Q-H, et al. Expression of heat-shock proteins is associated with major adverse prognostic factors in acute myeloid leukemia. Leuk Res. 2005;29:1049-58.

137. Tang D, Abdul Khaleque MD, Jones EL, Theriault JR, Li C, Wong WH, et al. Expression of heat shock proteins and heat shock protein messenger ribonucleic acid in human prostate carcinoma in vitro and in tumors in vivo. Cell Stress Chaperones. 2005;10:46-58.

138. Bauer KM, Lambert PA, Hummon AB. Comparative label-free LC-MS/MS analysis of colorectal adenocarcinoma and metastatic cells treated with 5fluorouracil. Proteomics. 2012;12:1928-37.

139. Faroog M, Hozzein WN, Elsayed EA, Taha NA, Wadaan MAM. Identification of Histone Deacetylase 1 Protein Complexes in Liver Cancer Cells. Asian Pac J Cancer Prev. 2013;14:915-21.

140. Wadhwa R, Takano S, Kaur K, Deocaris CC, Pereira-Smith OM, Reddel RR, et al. Upregulation of mortalin/mthsp70/Grp75 contributes to human carcinogenesis. Int J Cancer. 2006;118:2973-80.

141. Petrova DT, Asif AR, Armstrong WW, Dimova I, Toshev S, Yaramov N, et al. Expression of chloride intracellular channel protein 1 (CLIC1) and tumor protein D52 (TPD52) as potential biomarkers for colorectal cancer. Clin Biochem. 2008;41:1224-36.

142. Suehara Y, Kikuta K, Nakayama R, Tochigi N, Seki K, Ichikawa H, et al. GST-P1 as a histological biomarker of synovial sarcoma revealed by proteomics. PROTEOMICS - Clinical Applications. 2009;3:623-34.

143. Pucci-Minafra I, Cancemi P, Albanese NN, Di Cara G, Marabeti MR, Marrazzo A, et al. New Protein Clustering of Breast Cancer Tissue Proteomics Using Actin Content as a Cellularity Indicator. J Proteome Res. 2008;7:1412-8

144. Semaan SM, Wang X, Stewart PA, Marshall AG, Sang Q-XA. Differential phosphopeptide expression in a benign breast tissue, and triple-negative primary and metastatic breast cancer tissues from the same AfricanAmerican woman by LC-LTQ/FT-ICR mass spectrometry. Biochem Biophys Res Commun. 2011;412:127-31

145. Michael MZ, O' Connor SM, Van Holst Pellekaan NG, Young GP, James RJ. Reduced Accumulation of Specific MicroRNAs in Colorectal Neoplasia. Mol Cancer Res. 2003;1:882-91.

146. Li C, Tan YX, Zhou H, Ding SJ, Li SJ, Ma D, et al. Proteomic analysis of hepatitis B virus-associated hepatocellular carcinoma: Identification of potential tumor markers. Proteomics. 2005;5:1125-39.

147. Stephenson AJ, Smith A, Kattan MW, Satagopan J, Reuter VE, Scardino PT, et al. Integration of gene expression profiling and clinical variables to predict prostate carcinoma recurrence after radical prostatectomy. Cancer. 2005;104:290-8.

148. Erić A, Juranić Z, Milovanović Z, Marković I, Inić M, Stanojević-Bakić N, et al. Effects of Humoral Immunity and Calreticulin Overexpression on Postoperative Course in Breast Cancer. Pathol Oncol Res. 2009;15:89-90.

149. Toquet C, Jarry A, Bou-Hanna C, Bach K, Denis MG, Mosnier JF, et al. Altered Calreticulin expression in human colon cancer: Maintenance of Calreticulin expression is associated with mucinous differentiation. Oncol Rep. 2007;17:1101-7.

150. Chen CN, Chang CC, Su TE, Hsu WM, Jeng YM, Ho MC, et al. Identification of Calreticulin as a Prognosis Marker and Angiogenic Regulator in Human Gastric Cancer. Ann Surg Oncol. 2009;16:524-33.
151. Yoon GS, Lee $H$, Jung $Y$, Yu E, Moon HB, Song K, et al. Nuclear Matrix of Calreticulin in Hepatocellular Carcinoma. Cancer Res. 2000:60:1117-20.

152. Hong SH, Misek DE, Wang H, Puravs E, Giordano TJ, Greenson JK, et al. An Autoantibody-Mediated Immune Response to Calreticulin Isoforms in Pancreatic Cancer. Cancer Res. 2004;64:5504-10.

153. Alaiya A, Roblick U, Egevad L, Carlsson A, Franzén B, Volz D, et al. Polypeptide expression in prostate hyperplasia and prostate adenocarcinoma. Anal Cell Pathol. 2000;21:1-9.

154. Thomas PA, Kirschmann DA, Cerhan JR, Folberg R, Seftor EA, Sellers TA, et al. Association between Keratin and Vimentin Expression, Malignant Phenotype, and Survival in Postmenopausal Breast Cancer Patients. Clin Cancer Res. 1999;5:2698-703.

155. Fuyuhiro Y, Yashiro M, Noda S, Kashiwagi S, Matsuoka J, Doi Y, et al. Clinical Significance of Vimentin-positive Gastric Cancer Cells. Anticancer Res. 2010;30:5239-43.

156. Dauphin M, Barbe C, Lemaire S, Nawrocki-Raby B, Lagonotte E, Delepine G, et al. Vimentin expression predicts the occurrence of metastases in non small cell lung carcinomas. Lung Cancer. 2013;81:117-22.

157. Handra-Luca A, Hong SM, Walter K, Wolfgang C, Hruban R, Goggins M. Tumour epithelial vimentin expression and outcome of pancreatic ductal adenocarcinomas. Br J Cancer. 2011;104:1296-302.

\section{Submit your next manuscript to BioMed Central and we will help you at every step:}

- We accept pre-submission inquiries

- Our selector tool helps you to find the most relevant journal

- We provide round the clock customer support

- Convenient online submission

- Thorough peer review

- Inclusion in PubMed and all major indexing services

- Maximum visibility for your research

Submit your manuscript at www.biomedcentral.com/submit
C) Biomed Central 